\title{
Systematic Risk in Earnings and Expected Stock Returns
}

\author{
Jingjing Chen, Linda H. Chen and George J. Jiang*
}

This draft: April, 2020

\footnotetext{
* Jingjing Chen is from Department of Finance and Management Science, Carson College of Business, Washington State University. Email: jingjing.chen@wsu.edu. Linda H. Chen is from College of Business and Economics, University of Idaho. Email: lindachen@uidaho.edu. George J. Jiang is from Department of Finance and Management Science, Carson College of Business, Washington State University. Email: george.jiang@wsu.edu. The usual disclaimer applies.
} 


\title{
Systematic Risk in Earnings and Expected Stock Returns
}

\begin{abstract}
We propose a measure of systematic risk in corporate earnings, i.e., earnings beta, based on excess covariance between stock returns and market returns at the earnings announcement window. We show evidence that earnings risk is priced, but only when investors receive and trade on new information. Specifically, we find that earnings beta does not predict stock returns for the whole sample of stocks, but significantly and persistently predicts future stock returns for firms with earnings or M\&A announcements. A trading strategy long (short) stocks in high (low) beta quintiles among announcing firms earns an annualized 10.2\% Fama-French five-factor alpha. Moreover, we find that the premium of earnings risk is largely accrued around the date of earnings or M\&A announcement, and the results are stronger for firms with high earnings uncertainty, high trading activity, earlier announcements in an earnings cycle, and on-time announcements. Finally, we show that the premium of earnings risk also spillovers to non-announcing connected firms. The finding documented in our study appeals to an asset pricing theory somewhere between a simple behavioral model and a fully rational model.
\end{abstract}

Keywords: Earnings risk; Expected stock returns; Earnings announcements; M\&A announcements; Information arrival

JEL Classification: G12; G14 


\section{Introduction}

Earnings is undoubtedly the most important determinant of stock returns. Earnings announcement is the venue where the management disseminates information on firm performance to the market. When firms announce earnings, investors pay a great amount of attention as they not only update their expectation on individual firm performance but also extract information on aggregate earnings growth (Savor and Wilson, 2016). The component of earnings innovations that co-move with aggregate earnings innovations is an important source of systematic risk that directly links stock prices to firm fundamentals (Da and Warachka (2009)).

In this paper, we first propose a measure for systematic risk in corporate earnings and then examine the relation between earning risk and expected stock returns. We estimate systematic risk in earnings based on the excess covariance between stock returns and market returns or the excess market beta at the earnings announcement window. For the lack of a better term, we refer to this measure as earnings beta in this study. ${ }^{1}$ To illustrate what drives earnings beta or the excess covariance between stock returns and market returns at the earnings announcement window, we consider a simple earnings response model where abnormal stock returns are response to unexpected earnings news. Similar to the cash-flow model in Patton and Verardo (2012), innovations of a firm's earnings consist of both systematic component and firm-specific component. In response to earnings surprises, investors revise their expectations not only on announcing firm's cash flows but also on aggregate cash flows and incorporate such information into both announcing firm's stock prices and the overall market. ${ }^{2}$ As a result, the excess covariance

\footnotetext{
${ }^{1}$ By definition, earnings beta can be estimated based on the covariance between individual firm's earnings innovations and aggregate earnings innovations. On earnings announcements date, the estimates of earnings surprises are available for individual firms, either based on analyst forecasts or a seasonal random walk model, but not for the aggregate market, which renders the direct estimation of earnings beta infeasible.

${ }^{2}$ Similar to Savor and Wilson (2016), we show that average earnings announcement returns contain significant information on future aggregate earnings growth.
} 
between stock returns and market returns at the earnings announcement window captures the effect of the systematic component of a firm's earnings innovations. Our results show that consistent with Patton and Verardo (2012), there is on average a positive earnings beta during our sample period from 1980 to $2017 .{ }^{3}$ On average, small stocks, growth stocks, and past winners have higher earnings risk.

Under rational asset pricing theory, systematic risk in earnings should be priced by the market and thus should have a positive relation with expected stock returns. However, we find that for the whole stock sample, earnings beta does not predict future stock returns. In contrast, for stocks with earnings or M\&A announcements, earnings beta significantly and persistently predicts future stock returns. We interpret the finding as evidence that investor consumption of information is dictated by the information updating process. This is analogous to the voyage story used by Robichek and Myers (1966) to demonstrate the changes in risk prices. ${ }^{4}$ The price of risk intensifies at the time of new information arrival. For earnings risk to be incorporated into stock prices, investors have to process and trade on cash-flow related information. Specifically, our results show that sorting stocks with earnings or M\&A announcements into quintiles based on past earnings beta, stocks in the top earnings beta quintile have significantly higher returns than those in the bottom quintile. A value-weighted trading strategy long (short) stocks in high (low) beta quintiles among announcing firms earns an annualized 10.2\% Fama-French five-factor alpha. Moreover,

\footnotetext{
${ }^{3}$ Using intraday returns, Patton and Verardo (2012) estimate daily beta for stocks that are constituents of the S\&P 500 index over the period from 1996 to 2006. They find that, on average, the market beta of these stocks increases by a statistically and economically significant amount of 0.16 on announcement days.

${ }^{4}$ In the story by Robicheck and Myers (1966), a ship departs for a voyage in search for gold. The uncertainty is that the ship may not come back with gold. Suppose that during the trip new information cannot reach home, buying and selling financial claims on the payoffs of the voyage involves no change of risk days before the arrival of the ship. It is when the ship enters its home port and the uncertainty is resolved that the risk premium is incorporated into the price of financial claims.
} 
the premium of earnings beta is significantly positive over the next 12-month horizon, suggesting that earnings risk is persistent across stocks.

We show that the results are robust when we control for various firm characteristics in multivariate regressions. One potential concern is that since our earnings beta is estimated at the earnings announcement window and the risk premium is significant only for firms with earnings announcements, our result may be driven by market underreaction to earnings surprise or the socalled post-earnings announcement drift. We explicitly include lagged earnings surprise as a control variable and show that the results remain robust. To include the effect of nonsynchronous trading, we also estimate the earnings beta following Dimson (1979) approach and show that the results are consistent. We also include the VAR cash-flow beta proposed in Campbell and Vuolteenaho (2004) and Campbell, Giglio, Polk and Turley (2018) and quarterly earnings beta, estimated from quarterly earnings growth, as control variables. Our results show that even after controlling for the VAR cash-flow beta and quarterly earnings beta, the relation between earnings beta and stock returns remains positive and significant.

To substantiate our argument that earnings risk is priced when investors process and trade on new information, we perform several further analyses. First, we decompose monthly stock returns into announcement returns, i.e., cumulative returns at the earnings or M\&A announcement window, and non-announcement returns. If the price of risk indeed intensifies at the arrival of new information as depicted in Robichek and Myers (1966), we expect the premium of earnings risk to be accrued mostly around announcement date. Our results show that for firms with earnings or M\&A announcements, earnings beta has a significantly positive relation with future announcement returns but no significant relation with non-announcement returns. The cross-sectional regression implies a 0.092\% earnings risk premium over the six-day earnings announcement window [-1, 4]. 
Our results show that the VAR cash-flow beta in Campbell, Giglio, Polk and Turley (2018) also has a significantly positive relation with announcement returns. This finding is important since it helps further alleviate the concern that our finding may be driven by market underreaction to earnings surprises.

Second, we show that our results are stronger for firms with high ex ante earnings uncertainty and high trading activity. For firms with high earnings uncertainty, the arrival of new information resolves relatively more uncertainty on cash flows. The literature also documents that with more investor attention or trading activity, information is more efficiently incorporated into asset prices (Hirshleifer, Lim and Teoh, 2009). We use two proxies for ex ante earnings uncertainty: standard deviation of past earnings surprises (Zhang, 2006) and analyst coverage, and two proxies for investor attention: excess turnover and excess trading volume (Gervais, Kaniel and Mingelgrin, 2001; Barber and Odean, 2008; Chen, Jiang and Zhu, 2018). Our results confirm that the premium of earnings risk is significant for firms with high earnings uncertainty and high trading activity.

Third, we show that there are significant effects of announcement timing on the price of earnings risk. We focus on two aspects of announcement timing in our analysis. One is when firms announce earnings earlier relative to other firms in an earnings cycle, the other is when firms announce earnings timely relative to their own expected announcement dates. The literature shows that early announcements in an earnings cycle contain more information (Foster, 1981; Freeman and Tse, 1992). Savor and Wilson (2016) show evidence that early announcers are more informative of aggregate cash flows. The literature also shows that there is a higher earnings response coefficient for on-time announcers (Chambers and Penman, 1984; Atiase, Bamber and Tse, 1989; Ball and Kothari, 1991). When the date of upcoming announcement is known and the 
arrival of new information is anticipated, investors may gauge more precisely the unexpected component in the announcement based on ex ante expectations and price the systematic earnings risk more rationally. As shown in Ben-Rephael, Carlin, Da and Israelsen (2019), there is more information consumption by institutional investors around pre-scheduled announcement. We identify early and on-time earnings announcements and show that the premium of earnings risk is significant for early announcers in an earnings cycle and firms with on-time earnings announcements.

Finally, under the simple learning model of Patton and Verardo (2012), investors use information from announcing firms to update their expectations on the profitability of nonannouncing firms. Similarly, Savor and Wilson (2016) argue and show supporting evidence that investors extract common shocks in cash flows from individual firms' earnings announcements. As a result, the information consumption on cash flows may spillover to firms that are similar but have no earnings or M\&A announcements. Ben-Rephael, Carlin, Da and Israelsen (2019) construct an information consumption measure based on institutional attention and show that when institutional investors consume information due to the spillover effect, stocks have a significant risk premium and CAPM works. For each announcing firm, we identify a non-announcing connected firm with similar size in the same industry. We find that for non-announcing connected firms, earnings beta also positively predicts stock returns at announcing firms' announcement window. The results suggest that due to the spillover effect, investors consume information released by announcing firms and price the systematic risk in earnings for related firms as well.

Our study makes several contributions to the literature. First, we propose a measure of systematic risk in corporate earnings. Our measure is closely related to the earnings beta proposed in Da and Warachka (2009) using analyst earnings forecast revision. Relative to the quarterly 
reporting of earnings information by firms, analysts revise earnings forecasts more frequently. In comparison, our earnings beta is based on information update from the management, which often contains large unexpected shocks. Our measure is also related to the cash-flow beta proposed by Campbell and Vuolteenaho (2004) who decompose market beta into cash-flow beta ("bad beta") and discount-rate beta ("good beta”). As emphasized in Campbell and Vuolteenaho (2004), their cash-flow beta captures cash-flow risk from the perspective of long-term investors. In comparison, our earnings beta explores cash-flow information in quarterly earnings. One advantage of our earnings beta is that the estimates are available for a large sample of stocks over a long sample period since the estimation only requires earnings announcement dates and daily stock returns. Second, our study is closely related to Savor and Wilson (2016) who propose a risk-based explanation of the earnings announcement premium. We propose a measure for systematic risk in earnings under a conventional CAPM framework with clear economic interpretation and focus on not just whether but when earnings risk is priced across stcoks. Third, our study adds to the literature on information spillover. Our findings on non-announcing connected firms are consistent with the spillover effect in investor information consumption documented in Ben-Rephael, Carlin, Da and Israelsen (2019). Fourth, a large number of studies have examined the relation between systematic risk and expected stock returns with mixed evidence. ${ }^{5}$ We show evidence that the systematic risk in earnings risk is not consistently priced by the market, except when information is updated and risk is intensified. Such evidence does not support predictions of simple behavior models where risk is not priced or even mispriced, nor predictions of a fully rational model where

\footnotetext{
${ }^{5}$ Over the past few decades, empirical asset pricing literature has documented evidence challenging the validity of CAPM. While some papers report evidence that CAPM performs well during special times (Tinic and West, 1984; Cohen, Polk and Vuolteenaho, 2005; Hendershott, Livdan and Rösch, 2018), many studies show that high-beta stocks do not earn higher excess returns than low-beta stocks (Black, Jensen and Scholes (1972); Reinganum (1981); Fama and French (1992) Lewellen and Nagel (2006) Polk, Thompson and Vuolteenaho (2006) and Frazzini and Pedersen (2014).
} 
risk is consistently incorporated into stock prices. The evidence is consistent with the intuition established in Robichek and Myers (1966) and results presented in Savor and Wilson (2014) who find that the market prices CAPM beta only on pre-scheduled macroeconomic news announcement days. These findings appeal to a new asset pricing theory somewhere between a simple behavioral model and a fully rational model.

The rest of the paper is structured as follows. Section 2 describes the data and the estimation method of earnings beta. Section 3 presents the main empirical results on the relation between earnings beta and expected stock returns. Section 4 provides further analysis on the mechanism of the pricing of earnings beta. Section 5 concludes.

\section{Data and Methodology}

\section{A. Data}

The data used in our empirical analysis include stock returns from Center for Research in Security Prices (CRSP), other firm characteristics from Compustat, institutional ownership from Thomson-Reuters 13F filings and analyst coverage from Thomas Reuters Institutional Brokers’ Estimate System (IBES). The sample includes stocks with CRSP share code of 10, 11, 12, 18, 48 and 72, i.e., all common stocks and Real Estate Investment Trusts (REITs) listed on the US market. We exclude American Depository Receipts (ADRs), Exchange Traded Funds (ETFs), and closedend funds. The sample period is from January 1982 to December 2017. Our whole sample includes on average 3,557 of stocks per month with 1,536,746 firm-month observations.

Firm characteristics used in the empirical analysis include size (LNSIZE), book-to-market ratio (LNBM), momentum (MOM), idiosyncratic volatility (IVOL), illiquidity ratio (ILLIQ), lagged returns (LRET), leverage ratio (LEV), institutional ownership (IO), analyst coverage 
(COV) and lagged earnings surprise (LSUE). LNSIZE is the natural log of market capitalization using June size of a year. LNBM is the natural log of book-to-market ratio as defined in Fama and French (2008). MOM is momentum calculated as skip 1-month lagged 11-month cumulative returns. IVOL is idiosyncratic volatility in percentage relative to Fama-French three-factor model estimated based on daily returns over previous month. ILLIQ is Amihud (2002) illiquidity ratio pre-multiplied by $1,000,000$ based on daily returns over previous three months. LRET is lagged monthly return. LEV is leverage ratio calculated as total debt divided by the market value of the firm. IO is institutional ownership based on the most recent quarter. COV is analyst coverage defined as the number of analysts following the firm in the recent quarter. LSUE is lagged earnings surprise in the recent quarter based on seasonal random walk model. Table 1 reports time series average of monthly cross-sectional statistics of firm characteristics. The sample has a median market capitalization of \$246 million.

We obtain earnings announcement dates from both IBES and Compustat. Following Patton and Verardo (2012), we use IBES announcement date if the date has a valid announcement time. We adjust the announcement date to the next trading date if the announcement occurs after 4:00 p.m. for assessing the market reaction. For announcement dates with no precise announcement time, we use the earlier dates between IBES and Compustat (DellaVigna and Pollet, 2009). Merger and Acquisition announcement dates are obtained from Securities Data Corporation (SDC) platinum. We identify Merger and Acquisition announcement dates of acquiring firms for deals with more than $\$ 1$ million transaction value and acquirer owning less than $50 \%$ of the target before the transaction (Ma, Whidbee and Zhang, 2019). There are on average 3,280 earnings announcements per quarter and 111 Merger and Acquisition announcements per quarter. 


\section{B. Estimation of Earnings Beta}

In this paper, we estimate earnings risk based on stock returns during earnings announcement window. When firms announce earnings, stock returns during earnings announcement window are driven largely by unexpected earnings news. Specifically, we estimate the earnings beta for each stock based on CAPM model with variations from the following regression:

$$
R_{i, t}=\alpha_{i}+\left(\beta_{i}+\beta_{i}^{E A} d^{E A}\right) R_{m, t}+\varepsilon_{i, t}
$$

where $R_{i, t}$ is firm i's return in excess of risk free rate, $R_{m, t}$ is excess market return (mktrf) from Ken French's Website, and dummy variable $d^{E A}=1$ at announcement window $[-1,0,1]$ and zero otherwise. Ball and Kothari (1991) estimate stock beta over a three-day window around earnings announcements and document an increase of about $6.7 \%$ in market beta over the announcement window. The model in Eq. (4) is a simple extension of the CAPM:

$$
E\left(r_{i}\right)=r_{f}+\beta_{i}^{C A P M}\left[E\left(r_{m}\right)-r_{f}\right]
$$

and $\beta_{i}^{C A P M}$ relates to $\beta_{i}^{E A}$ as follows $\beta_{i}^{C A P M}=\beta_{i}+\beta_{i}^{E A} d^{E A}$, where $d^{E A}=1$ if the return is observed during the earnings announcement window and zero otherwise. In essence, the earnings beta simply captures the excess covariance between stock returns and market returns during the earnings announcement window.

To illustrate what drives $\beta_{i}^{E A}$, consider a simple earnings response model where stock price of firm i changes during earnings announcement window in response to earnings surprises $\left(\ln I_{i, t+1}-E_{t}\left[\ln I_{i, t+1}\right]\right):$

$$
\begin{aligned}
R_{i, t+1} & =F_{i}\left(\ln I_{i, t+1}-E_{t}\left[\ln I_{i, t+1}\right], X_{i, t}\right) \\
& =E_{t}\left[R_{i, t+1}\right]+F_{i, 1}^{\prime}(\cdot)\left(\ln I_{i, t+1}-E_{t}\left[\ln I_{i, t+1}\right]\right)
\end{aligned}
$$


where $X_{i, t}$ are firm characteristics that affect stock returns, and $F_{i, 1}^{\prime}(\cdot)$ is the earnings response coefficient (ERC). The second equation is based on an approximation of Taylor expansion and shows that abnormal stock returns at earnings announcement is directly related to unexpected earnings news. Similar to the cash-flow model in Patton and Verardo (2012), earnings innovations of firm i can be decomposed into systematic component and firm specific component:

$$
\operatorname{lnI}_{i, t+1}-E_{t}\left[\ln _{i, t+1}\right]=g_{i, t}+\gamma_{i}\left(\ln I_{t+1}-E_{t}\left[\ln I_{t+1}\right]\right)+u_{i, t+1}
$$

where $g_{i, t}$ is the earnings growth rate, and $\ln I_{t+1}-E_{t}\left[\ln I_{t+1}\right]$ are innovations to aggregate earnings, and $\gamma_{i}$ measures the extent to which firm i's earnings innovations are exposed to aggregate earnings innovations. ${ }^{6}$ That is, $\gamma_{i}$ determines the effect of systematic earnings innovations on abnormal stock returns at the earnings announcement window. When a firm i's earnings innovation contains no systematic effect, i.e., $\gamma_{i}=0$, there is no systematic risk in firm i's earnings. On the other hand, when $\gamma_{i}$ is high, abnormal stock returns at the earnings announcement window contain significant information on aggregate earnings shocks. The higher the systematic component is, the higher the covariance between stock returns and market returns on earnings announcement days. Similar to Savor and Wilson (2016), we show that average earnings announcement returns contain significant information on future aggregate earnings growth. The results are reported in Appendix, Table A1.

As noted earlier, Patton and Verardo (2012) estimate daily beta using intraday highfrequency data. In this study, we use daily returns which are available for a large sample of stocks

\footnotetext{
${ }^{6}$ As noted earlier, direct estimation of $\gamma_{i}$ is infeasible because observations of aggregate earnings innovations are unavailable on earnings announcement date.
} 
over a long sample period. We obtain estimates of monthly earnings beta, $\beta_{i}^{E A}$ based on past daily returns over 3-year rolling window with at least 2 years of observations. ${ }^{7}$

With data in daily frequency, beta is commonly estimated using Dimson (1979) estimation approach to address the concern of potential nonsynchronous trading. We estimate earnings beta following the Dimson (1979) approach, $\beta_{i}^{E A(D)}$, by incorporating a leading and a lagged market return.

$$
R_{i, t}=\alpha_{i}+\sum_{k=-1}^{1}\left[\left(\beta_{i, k}+\beta_{i, k}^{E A} d^{E A}\right) R_{m, t+k}\right]+\varepsilon_{i, t}
$$

Earnings beta using Dimson (1979) estimation approach is hence given by the sum of slope coefficients from Eq. (5), i.e. $\beta_{i}^{E A(D)}=\sum_{k=-1}^{1} \beta_{i, k}^{E A}$. Results based on earnings beta using Dimson (1979) estimation approach are consistent with those based on simple earnings beta.

In addition to the above estimates of earnings beta, we also implement alternative measures of cash-flow risk. One is the vector autoregression (VAR) implied cash-flow beta proposed in Campbell and Vuolteenaho (2004), Campbell, Polk and Vuolteenaho (2010) and Campbell, Giglio, Polk and Turley (2018). Campbell, Giglio, Polk and Turley (2018) use a vector autoregression (VAR) to capture time variation in expected returns and volatitlity. They derive the log stochastic discount factor (SDF) of interemporal CAPM for incorporating stochastic volatility:

$$
\begin{aligned}
m_{t+1}-E_{t} m_{t+1}= & -\gamma\left[r_{t+1}-E_{t} r_{t+1}\right]-(\gamma-1) N_{D R, t+1}+\frac{1}{2} N_{R I S K, t+1} \\
& =-\gamma N_{C F, t+1}-\left[-N_{D R, t+1}\right]+\frac{1}{2} N_{R I S K, t+1}
\end{aligned}
$$

where $m_{t+1}$ denotes $\log \mathrm{SDF}, r_{t+1}$ denotes future log return, $\gamma$ denotes the risk price, $N_{C F}$ denotes cash-flow news, $N_{D R}$ denotes discount-rate news, and $N_{R I S K}$ denotes future risk news. The log SDF

\footnotetext{
${ }^{7}$ We estimate earnings beta based on another estimation window using 5-year rolling window with at least 3 years of observations and obtain similar results for our analysis. Our results are also robust to different announcement window for constructing announcement dummy.
} 
is expressed by the market return, future dicount rate and risk news. The market return is then decomposed into cash-flow news and discount-rate news. Campbell and Vuolteenaho (2004) refer to beta associated with cash-flow news as "bad beta" and beta associated with discount-rate news as "good beta". A third term of risk news captures the shocks to long-run expected future volatility (Campbell, Giglio, Polk and Turley, 2018). To obtain the empirical estimates of the news terms, Campbell, Giglio, Polk and Turley (2018) implement a first-order VAR which includes six state varaibles: the real market return, expected market variance, price-smoothed earnings ratio, yield on the three-month Treasury bill, small-stock value spread and default spread. We use the same cash-flow news component $\left(N_{C F}\right)$ and discount rate news component $N_{D R}$ as in Campbell, Giglio, Polk and Turley $(2018)^{8}$ and define VAR cash-flow beta as

$$
\beta_{i}^{C F(V A R)}=\frac{\operatorname{Cov}\left[r_{i, t}, N_{C F, t}\right]}{\operatorname{Var}\left[r_{M, t}-E_{t-1} r_{M, t}\right]}
$$

where $r_{M, t}-E_{t-1} r_{M, t}=N_{C F, t+1}-N_{D R, t+1}$ as in Campbell and Vuolteenaho (2004) and Campbell, Giglio, Polk and Turley (2018). Aligning with our earnings beta, we estimate individual stock VAR cash-flow beta based on monthly returns and news terms of the most recent quarter over 3-year rolling window with at least 18-month observations.

The other appoach of measureing cash-flow risk is to estimate earnings beta directly based on firms' quartely earnings. We obtain quarterly net income $\left(e_{i, t}\right)$ from Compustat. $P_{i}$ is the market capitalization of firm i. Earnings growth of individual stock is computed as $g_{i, t}=\frac{e_{i, t}-e_{i, t-4}}{P_{i, t-4}}$ and earnings growth of the aggregate market is given by $a g g_{-} g_{t}=\frac{a g g_{-} e_{t}-a g g_{-} e_{t-4}}{a g g_{-} P_{t-4}}$. We then regress individual earnings growth on the aggregate earnings growth following Eq. (8) and obtain

\footnotetext{
${ }^{8}$ The quarterly time series of the six state variables and three news terms are available up to 2011 from Christopher Polk's website. We thank Christopher Polk for sharing the data.
} 
quarterly earnings beta $\left(\beta_{i}^{Q E}\right)$ which captures the covariation between firm's cash flows and aggregare cash flows.

$$
g_{i, t}=\alpha_{i}+\beta_{i}^{Q E} a g g_{-} g_{t}+\varepsilon_{i t}
$$

The quartely earnings beta is estimated over 5-year rolling window with at least 6-quarter observations. We truncate beta estimates at $0.1 \%$ and $99.9 \%$ percentile to remove the effect of outliers.

Table 2 reports the estimates of earnings beta, CAPM beta and VAR cash-flow beta and quarterly earnings beta. The full sample has an average earnings beta of 0.031 and 0.058 for earnings beta under Dimson (1979) estimation approach. Earning beta is positive implying that CAPM beta experiences an increase during earnings announcement days, which is consistent with Patton and Verardo (2012). The magnitude is smaller than that in Patton and Verardo (2012). In addition to the use of daily returns, this is in part likely due to the fact that Patton and Verardo (2012) includes stocks in the S\&P 500 index, whereas our sample includes all stocks. For size subsamples in Panel B, small stocks have higher cross-sectional mean and standard deviation of earnings beta than big stocks. Consistent with Campbell and Vuolteenaho (2004), small stocks have higher VAR cash-flow betas than big stocks. For B/M subsamples in Panel C, earnings betas are larger for growth stocks than for value stocks. The mean of VAR cash-flow beta for value stocks is similar to the mean of growth stocks ${ }^{9}$. The average of quarterly earnings beta is, however, higher for value stocks. In Panel D, we divide the sample according to long-term return reversal which is skipping one-year past three-year returns. Long-term losers have smaller earnings betas

\footnotetext{
${ }^{9}$ According to Campbell, Giglio, Polk and Turley (2018), their cash-flow beta is slightly higher for value stocks than for growth stocks in the period of 1963-2011. Since our sample period starts from 1980, we calculate statistics of VAR cash-flow beta for B/M subsamples during 1963-1979 and verify that value stocks do have higher VAR cash-flow betas than growth stocks in earlier period.
} 
than long-term winners. VAR cash-flow betas are similar for both losers and winners. Similar to Da and Warachka (2009), quarterly earnings betas for past long-term losers are larger than those of past long-term winners. Panel E shows that higher earnings beta is related to higher CAPM beta but is unrelated to either VAR cash-flow beta or quarterly earnings beta.

\section{Main Empirical Analysis}

\section{A. Earnings beta and Stock Returns}

As an important source of systematic risk, systematic risk in earnings should contain a positive risk premium. We start our main analysis on the relation between earnings beta and stock returns with portfolios sorted on earnings beta. Each month, quintile portfolios are formed based on earnings beta estimated at the end of month t. We then calculate average monthly returns and abnormal returns in month $t+1$ of both equal-weighted and value-weighted quintile portfolios. If earnings beta is priced, the market should demand higher expected returns for stocks with higher earnings betas. We expect the differences in abnormal returns between stocks in the highest and lowest quintiles to be significantly positive.

Table 3 reports average monthly returns, Fama and French (1993) three-factor and Fama and French (2015) five-factor alphas for quintile portfolios sorted on earnings beta in the whole sample. The table also reports return and alpha spreads between the highest and lowest quintiles. The t-statistics are based on Newey-West standard errors with three lags. The results in Table 3 show that the spreads in average returns, FF3 and FF5 alphas between the top and bottom quintiles are insignificant for the whole sample. The average returns among different quintiles are similar.

We next partitioned firms into two subsamples: those with earnings announcements and those without. The results in Table 4 show that the abnormal returns for firms with earnings 
announcement are positive, whereas the abnormal returns for firms without earnings announcement are mostly negative. This is consistent with the earnings announcement premium documented in early studies by, e.g., Beaver (1968), and recent studies by, e.g., Savor and Wilson (2016). More importantly, the results show that the cross-sectional relation between earnings beta and stock returns is different for firms with earnings announcements than those without. In Panel A of Table 4, both the return and alpha spreads between the top and bottom quintiles are positive and significant for firms with earnings announcements. For equal-weighted portfolios, average returns increase monotonically from Q1 portfolio, which contains the lowest earnings beta stocks, to Q5 portfolio, which contains the highest earnings beta stocks. The equal-weighted long-short portfolio, i.e. a strategy of buying the highest quintile stocks and selling the lowest quintile stocks, yields a FF5 abnormal return of $0.29 \%$ per month with t-statistic of 2.70 . For value-weighted portfolios, average returns increase from $1.18 \%$ per month for Q1 portfolio to $1.47 \%$ per month for Q3 portfolio and further rising to 1.79\% per month for Q5 portfolio. The difference in FF5 alphas between Q1 and Q5 is 0.81\% per month with t-statistics of 3.19. That is, a value-weighted trading strategy long (short) stocks in high (low) beta quintiles among announcing firms earns an annualized 10.2\% Fama-French five-factor alpha. The spreads in returns and alphas for valueweighted portfolios is larger indicating that the results are not driven by small stocks. When firms have no earnings announcement in the month, the return and alpha spreads are not significantly different from zero and some are even negative. This is consistent with the full sample results. We also incorporate M\&A announcements into announcement information set and obtain similar results. We interpret the findings as evidence that price of risk intensifies when firms provides updating information related to fundamentals. Investors form expectations prior to the announcements. When new information arrives, investors observe the unexpected earnings and 
revise their expectations. To incorporate earnings risk into stock prices, investors have to process and trade on cash-flow related information.

Since firms report earnings regularly on a quarterly frequency, earnings betas are not updated over a three-month cycle. In Panel B, Table 4, we use three-month average portfolio returns to examine whether high earnings beta is related to high average returns over the next three months. The result shows that the cash-flow risk and return pattern over the three-month cycle is similar to the monthly-updating risk and return pattern. Overall, for announcing firms, portfolio with high earnings beta stocks has higher average returns than portfolio with low earnings beta stocks. The result suggests that earnings beta is priced in the cross-section when there is information updating for the firm.

To test whether earnings beta is persistent, we examine the relation between historical earnings beta and announcement returns over longer horizon. If past earnings beta does not change rapidly, we expect past earnings beta to proxy for current systematic risk in earnings, and firms with high past earnings beta shows high future returns. In table 5, we form quintile portfolios separately for announcing and non-announcing firms based on earnings beta in month $t$ and calculate returns and alphas over the next 6 and 12 months. The return spreads for stocks with earnings announcements between the top and bottom quintiles are significantly positive up to the next 12 months suggesting that systematic risk in earnings is persistent across stocks. For firms without earnings announcements, past earnings betas are not reflected in average future stock returns. 


\section{B. Robustness Checks: Multivariate Regressions}

To control for firm characteristics, we further perform multivariate regressions to test the robustness of the positive relation between earnings beta and expected returns. We run following Fama-MacBeth cross-sectional regressions.

$$
R_{i, t+1}=\gamma_{0, t}+\gamma_{1, t} d_{i, t+1}^{A N N} \hat{\beta}_{i, t}^{E A}+\gamma_{2, t} d_{i, t+1}^{N A N N} \hat{\beta}_{i, t}^{E A}+\gamma_{3, t} d_{i, t+1}^{A N N}+\text { Controls }+\varepsilon_{i, t}
$$

where $\hat{\beta}_{i, t}^{E A}$ is earnings beta in month $\mathrm{t}$. The announcement dummy is defined as $d_{i, t+1}^{A N N}=1$ if firm $i$ has earnings announcement in month $t+1$. When $M \& A$ announcements are incorporated into the information set, the announcement dummy is defined as $d_{i, t+1}^{A N N}=1$ if firm i has either earnings or M\&A announcement in month $\mathrm{t}+1 . d_{i, t+1}^{N A N N}$ is the dummy for non-announcing firms, defined as 1$d_{i, t+1}^{A N N}$. The coefficient $\left(\gamma_{1}\right)$ of the interaction term between $d^{A N N}$ and $\hat{\beta}^{E A}$ is the risk price associated with earnings beta for firms with announcements. $\gamma_{2}$ is the coefficient of the interaction term between $d^{N A N N}$ and $\hat{\beta}^{E A}$, which is the price of earnings risk for firms with no announcement. $\gamma_{3}$ is the coefficient of announcement dummy, which captures the announcement premium. We test $\gamma_{1}$ and $\gamma_{2}$ to examine whether earnings beta is priced. Control variables include $\beta^{C A P M}$, LNSIZE, LNBM, MOM, IVOL, ILLIQ, LRET, LEV, IO and COV. Since our earnings beta is estimated at the earnings announcement window and the risk premium is significant only for firms with earnings announcements, to eliminate the potential concern of market underreaction to earnings surprises or post-earnings announcement drift, we explicitly include lagged earnings surprise (LSUE) as a control variable. For details of control variables, please see Table 1.

Table 6 reports multivariate regression results of earnings beta and stock returns. Panel A shows average estimates of Fama-MacBeth cross-sectional regressions in Eq. (9) and Newey-West t-statistics with 12 lags. We find a significantly positive relation between past earnings beta and monthly stock returns for firms with earnings or M\&A announcements. The earnings beta 
coefficient for firms with earnings announcement is significant and positive at $0.093 \%$ per month, suggesting that higher earnings betas predict higher monthly returns. Including M\&A announcements, we show that the explanatory power of earnings beta is slightly stronger. The average slopes of earnings beta for firms with either earnings or M\&A announcements is $0.095 \%$ with t-statistics of 2.85. The positive and significant relation between past earnings beta and stock returns is robust after controlling firm characteristics, including lagged earnings surprise.

In contrast to the strong explanatory power of past earnings beta for announcing firms, the risk premium associated with earnings beta for non-announcing firms is insignificant. The average slope of earnings beta is $-0.002 \%$ for firms with no earnings announcement and $-0.003 \%$ for firms with neither earnings nor M\&A announcement. The coefficient of earnings beta for firms with earnings announcements is $0.095 \%$ higher than for firms without earnings announcement. In other words, the market does not price earnings risk when firms have no updated cash-flow information.

The coefficient of announcement dummy, $d^{A N N}$ is positive and significant indicating the earnings announcement premium documented by prior literature (Beaver, 1968; Frazzini and Lamont, 2007; Barber, De George, Lehavy and Trueman, 2013; Savor and Wilson, 2016). Stock returns are negatively related to LNSIZE, IVOL, LRET and LEV, and positively related to LNBM, ILLIQ and LSUE.

The results are confirmed by performing panel regressions following Eq. (10) using standard errors clustered by time.

$$
R_{i, t+1}=\gamma_{0}+\gamma_{1} d_{i, t+1}^{A N N} \hat{\beta}_{i, t}^{E A}+\gamma_{2} d_{i, t+1}^{N A N N} \hat{\beta}_{i, t}^{E A}+\gamma_{3} d_{i, t+1}^{A N N}+\text { Controls }+\delta_{t}+\varepsilon_{i, t}
$$

where $\delta_{t}$ is time fixed effects for each month. Other variables are the same as those in Eq. (9). Panel B of Table 6 shows that earnings beta is positively and significantly priced for firms with earnings or M\&A announcements. The coefficient of earnings beta is $0.070 \%$ for firms with 
earnings announcements and $0.073 \%$ for firms with either earnings or M\&A announcement. The implied risk premium of earnings beta for announcing firms is robustly positive and significant in multivariate regressions. Not surprisingly, the coefficient of earnings beta for non-announcing firms remains negative and insignificant in panel regression.

We also replicate the regressions using $\beta^{E A(D)}$ estimated following the Dimson (1979) in Eq. (5). The results are similar and stronger reported in Appendix, Table A2.

\section{Robustness Checks: Other Measures of Cash-flow Risk}

To futher exmine the robustness of the main findings, Table 7 and Table 8 test the expanation power of other measures of cash-flow risk, and the robustness of our earnings beta when VAR cash-flow beta or quarterly earnings beta is included as a control variable. The analysis serves two purposes. First, we are inetrerested in whether VAR beta has predictive power of future stock returns. Second and more importantly, we are interested in whether one measure subsumes the predictive power of the other. In general, VAR cash-flow beta coefficient is positive but inisignificant. As shown in model (4)-(5) of Table 7, our main results are robust after controlling for VAR cash-flow beta. In addition, we estimate VAR discount-rate beta to include it as a control variable. We show that discount-rate beta has little effect on the results, see Model (3) and (5) of Table 7.

In terms of a direct measure of cash-flow risk, quarterly earnings beta does not explain the cross-section of stock returns. Table 8 reports that the quarterly earnings beta coefficient is negative and insignificant for both announcing firms and non-announcing firms. The relation between our earnings beta and stock returns remains positive and significant after controlling for quarterly earnings beta. Overall, our earnings beta shows favorable explanation power against two cash-flow risk measures. 


\section{Further Analysis}

In this section, we provide further analysis to substantiate our argument that during the time when information on firm fundamentals is updated and investors process and trade on new information, earnings risk premium is incorporated into stock prices. We first test whether the premium of systematic risk in earnings is concentrated around the arrival of new information. We then exploit variations in investor processing and trading around announcements to shed light on the influence of earnings beta and return relation. Moreover, we test the implications of announcement timing on the price of earnings risk. Finally, to the extent that information spillovers from announcing to non-announcing firms, we examine whether earnings beta is priced for nonannouncing firms when investors consume information from announcing firms.

\section{A. Earnings beta and Announcement Returns}

We decompose monthly stock returns into announcement returns and non-announcement returns. Announcement returns reflect market reactions to the release of news on firm fundamentals. If positive risk premium of earnings beta is accrued at the arrival of information (Robichek and Myers, 1966), we expect that earnings beta and return relation for announcing firms is driven by announcement returns.

Table 9 presents average estimates of Fama-MacBeth cross-sectional regressions of announcement and non-announcement returns on earnings beta and other control variables for announcing firms. Announcement return is defined as cumulative stock return over announcement window $[-1,4]$. The announcement window begins at day -1 in correspond with the estimation window of earnings beta and ends at day 4 to allow enough time for information to be incorporated 
into prices. Non-announcement return is defined as monthly return excluding announcement return.

In Panel A of Table 9, using announcement returns as dependent variable, we find that higher earnings betas predict higher announcement returns. The earnings beta coefficient is positive and significant suggesting that the implied earnings risk premium is $0.072 \%$ over the sixday earnings announcement window $[-1,4]$. The results are slightly stronger when we include M\&A announcements. The findings document that about $77 \%$ of the implied risk premium associated with earnings beta is concentrated around the dates when information on firm fundamentals arrives.

Since our earnings beta is estimated based on earnings announcement returns, one potential concern is that the earnings beta and announcement return relation may be driven by market constant underreaction to earnings surprises. We implement VAR cash-flow beta which is based on cash-flow news derived from the perspective of long-term investors. We find that VAR cashflow beta also has a significantly positive relation with announcement returns. After controlling for VAR cash-flow beta, the premium of our earnings beta during announcement window is still robust.

Moreover, Panel B of Table 9 shows that, using non-announcement return as dependent variable, the coefficient of earnings beta is insignificant. This further confirms that the premium of earnings beta is concentrated around the date of earnings or M\&A announcement. For robustness check, we find similar results using different announcement windows. Interestingly, the average slope of CAPM beta is significantly negative around announcement days but positive in normal days. In sum, we further show that the strong and positive relation between earnings beta and expected stock returns is mainly driven by the information updating process. This is 
consistent with our argument that the market prices earnings risk when information is updated and consumed.

\section{B. Effect of Earnings Uncertainty}

To further shed light on the implications of information processing on earnings beta and return relation, we exploit the variation in the extent to earnings uncertainty. If high announcement returns reflect earnings risk, we expect the relation to be stronger for firms with higher earnings uncertainty. For these firms, new information on corporate earnings resolves relatively more earnings uncertainty and risk-averse investors demand premium for earnings beta.

We first use standard deviation of historical earnings surprises as a proxy for ex ante earnings uncertainty (Zhang, 2006). First, we classify announcing firms according to monthly cross-sectional medians of standard deviations of historical earnings surprises. Then, we set dummy variable of high earnings uncertainty $\left(d^{H E U}\right)$ equal to 1 for firms with high standard deviations of historical earnings surprises and zero otherwise. Low earnings uncertainty dummy ( $d^{L E U}$ ) is defined as $1-d^{H E U}$. We examine the coefficient of the interaction terms between earnings beta and earnings uncertainty dummies. The results in Panel A, Table 10 show that the relation between earnings beta and announcement returns is stronger for firms with higher earnings uncertainty. The earnings beta coefficient of high earnings uncertainty group is $0.090 \%$ (t-statistics of 2.66) for firms with earnings announcements and $0.092 \%$ (t-statistics of 2.82) for firms with either earnings or M\&A announcements.

We use analyst coverage as a second proxy for earnings uncertainty. Firms with low analyst coverage are likely to have higher information uncertainty. We use residual analyst coverage which adjusts for firm size and define high and low earnings uncertainty dummies similarly. Panel B of Table 10 shows that the coefficients of earnings beta for low residual analyst coverage firms 
are positive and strongly significant. For firms with either earnings or M\&A announcements, earnings beta coefficient is $0.118 \%$ with t-statistics of 3.13 . The findings confirm that the positive relation between earnings beta and expected stock returns is stronger when the announcements resolve more earnings uncertainty.

\section{Effect of Investor Attention}

For cash-flow risk to be incorporated into stock prices, not only information needs to be processed but also investors need to trade on such information. Prior studies suggest that high investor attention gives rise to price efficiency while limited investor attention is related to mispricing. Hirshleifer and Teoh (2003) show that investors' neglect of information results in underreaction to news. Hirshleifer, Lim and Teoh (2009) find weaker reactions to earnings news and stronger post earnings announcement drift when there are more announcements released in the same day. With high trading activities, the process of information may be accelerated. We test the effect of investor trading activities on the pricing of earnings beta when firms have updating information. We use log excess turnover and log excess trading volume to proxy for investor attention (Gervais, Kaniel and Mingelgrin, 2001; Barber and Odean, 2008). We define log excess turnover (LNETO) and log excess trading volume (LNETV) as follows.

$$
\begin{gathered}
\operatorname{LNETO}_{i, t+1}=\operatorname{Ln}\left(\frac{T O_{i, t+1}[-1,4]}{T O_{i,[t, t-1]}}\right) \\
\operatorname{LNETV}_{i, t+1}=\operatorname{Ln}\left(\frac{T V_{i, t+1}[-1,4]}{T V_{i,[t, t-1]}}\right)
\end{gathered}
$$

where $T O_{i,[t, t-1]}$ is calculated as average daily turnover during the period of two months before the earnings announcement month $\mathrm{t}+1$ for firm $\mathrm{i}, T O_{i, t+1_{[-1,4]}}$ is the average daily turnover over announcement window $[-1,4]$ for firm $\mathrm{i}, T V_{i,[t, t-1]}$ is calculated as average daily trading volume during the period of two months before the earnings announcement month $t+1$ for firm $i$, and 
$T V_{i, t+1_{[-1,4]}}$ is the average daily trading volume over the announcement window [-1, 4] for firm i. Turnover is calculated as trading volume divided by shares outstanding. Trading volume is measured by daily dollar volume.

In Table 11, we show that earnings beta is positively related to announcement returns for firms with high log excess turnover. We find similar results using excess trading volume as another proxy for investor attention. Our results imply that high investor trading activities helps incorporate earnings risk into asset prices.

\section{Effect of Announcement Timing}

The literature documents a significant effect of announcement timing on the information content of announcements and investor reactions. Announcement timing is defined in two ways. The first aspect of timeliness is defined as the reporting lag between fiscal quarter end covered by the report and the announcement date of the report. We identify early announcers relative to other firms in an earnings cycle as having earnings announcement falling in the earliest quintile or tercile in a given fiscal quarter. Prior literature shows that the market learns more from early announcers in an earnings cycle (Foster, 1981; Freeman and Tse, 1992). Savor and Wilson (2016) show evidence that early announcements are more informative of aggregate cash flows than late announcements. Given that early announcers offer more informative signals about innovations to aggregate earnings, early announcers’ earnings innovations contain larger portion of the systematic component. We hence expect investors digest more from the information on early announcements and the reflection of earnings risk is stronger for early announcers.

In table 12, we find that the risk premium of earnings beta for early announcers in an earnings cycle is positively and strongly significant. Firms with earnings announcements falling in the earliest quintile of the earnings cycle have an implied earnings risk premium of $0.167 \%$ with 
t-statistics of 3.31 over the six-day announcement window $[-1,4]$. This is about four times higher than other firms which announce later in the earnings cycle. When we apply a broader definition based on the earliest tercile in the earnings cycle which leads to more early announcers in the sample, we show that the results are consistent.

The second aspect of announcement timing is when firms announce earnings timely relative to their own expected announcement dates. Previous studies show that there is a higher earnings response coefficient for on-time announcers (Chambers and Penman, 1984; Atiase, Bamber, and Tse, 1989; Ball and Kothari, 1991). When the date of upcoming announcement is known, investors are able to form expectations prior to the arrival of information. In anticipated events, investors may gauge more precisely the systematic component in earnings surprise and price the earnings risk more rationally. We exploit the timing of announcements to differentiate anticipated and unanticipated information event. To the extent that investors anticipate the arrival of information, we predict that the relation between earnings beta and returns is stronger for anticipated announcements.

Our analysis is based on expected announcement dates following So and Wang (2014). So and Wang (2014) find that return reversals as a proxy for expected returns demanded by market makers for providing liquidity are the largest for on-time announcements, less for late announcements and absence for early announcements. Evidence from So and Wang (2014) shows that the extent to which market participants is able to anticipate the information event is affected by the timing of announcements. We use on-time announcements to proxy for anticipated events. Firms with on-time announcements are defined as having actual earnings announcement dates occur within one or two trading days of expected announcement dates. There is about $30 \%$ of ontime announcements that overlap with early announcements in the earnings cycle. We divide the 
sample of announcing firms into firms with on-time and firms with early/late earnings announcements corresponding with anticipated and unanticipated information events.

Table 13 reports earnings beta coefficient estimates for on-time announcers and other announcers. We find that earnings beta of on-time announcers is positively and significantly priced with coefficient of $0.109 \%$ which is considerably higher than the coefficient for other announcers. We also relax the requirement of identifying on-time announcements by allowing two-day difference between the actual and expected announcement dates and find similar results. Overall, the findings suggest that the market prices earnings beta when investors anticipate more in the events.

\section{E. Effect on Non-announcing Connected Firms}

Investors extract the common component of a firm's earnings innovations and revise their expectations on the prospect of the rest of the economy (Patton and Verardo, 2012; Savor and Wilson, 2016). Information consumption on such cash-flow news may also spillover from announcing firms to non-announcing firms. Investors following a non-announcing firm may consume information from a similar announcing firm. Ben-Rephael, Carlin, Da and Israelsen (2019) show that when institutional investors consume information due to the spillover effect, stocks have a significant risk premium and CAPM works well. In this section, we investigate whether non-announcing firms respond to information provided by other firms with similar cashflow streams. We calculate announcement returns of the non-announcing firms based on announcement window $[-1,4]$ of the corresponding announcing firm. Given that information from other firms can also be consumed by investors, we expect earnings beta of the non-announcing connected firm to be priced when its corresponding announcing firm updates information. 
We identify connected firms based on industry using four-digit SIC code and firm size. We use industry and size as matching criteria since fundamentals of firms in the same industry tend to be similar and size is regarded as an important firm characteristic for investors. Non-announcing firms are matched to announcing firms with no replacement. For each month and each industry, we start the matching from announcing firms with the smallest size to the largest size. Then, the announcing firm is matched with a non-announcing firm based on the smallest size difference among all available size pairs. The total number of firm-month observations with non-announcing connected firms is 334,622 , which represents $71 \%$ of the sample for firms with earnings announcements. The time-series average number of industry is 229 .

As Table 14 shows, the relation between earnings beta and announcement returns is positive and significant for non-announcing connected firms. The earnings beta coefficient is considerably higher than the negative and insignificant coefficient for the whole non-announcing firms (see Table 6). The results also help to explain our findings on the effect of early announcers. When early announcers release earnings news, the market reacts strongly to these announcements as they contain more information about aggregate cash flows. In the meantime, the information also spillovers to late announcers. When these late announcers release earnings information, market reaction tends to be moderate as some of the information was incorporated into stock prices already. We also find that earnings beta predicts returns at $[0,5]$ announcement window better than returns at $[-1,4]$ announcement window. Using announcement returns at $[0,5]$ window, earnings beta coefficient is higher and more significant at $0.049 \%$ with t-statistics of 2.58 . This implies a lagged effect for information spillover. As information travels from the announcing firm to the non-announcing connected firm, it may require more efforts and time in processing information and learning across stocks. 


\section{Conclusion}

In this paper, we propose a measure of systematic risk in corporate earnings and examine whether and more importantly when the market prices earnings risk. We estimate earnings beta based on the excess covariance between stock returns and market returns at the earnings announcement window. We find that for the whole stock sample, earnings beta does not predict future stock returns. Nevertheless, for stocks with earnings or M\&A announcements, earnings beta significantly and persistently predicts future stock returns. We interpret the finding as evidence that earnings beta is priced when related information is produced by the management and consumed by investors. Consistent with the argument, we find that the premium of earnings risk is concentrated around the announcement window. We further show that the positive relation between earnings beta and stock returns is stronger for stocks with high earnings uncertainty, high investor attention, earlier announcements in an earnings cycle, and on-time announcements. Moreover, as information spillovers from announcing firms to the market, earnings risk is also priced for non-announcing related firms. The results confirm that the updating process of information seems to dictate how investors trade on information. As a consequence, the systematic risk in earnings is not consistently reflected in stock prices, instead it is priced only when investors process and trade on updated cash-flow information. The finding appeals to a new asset pricing theory, bridging the conventional rational camp and behavioral camp. 


\section{References}

Amihud, Yakov, 2002, Illiquidity and stock returns: Cross-section and time-series effects, Journal of financial markets 5, 31-56.

Atiase, Rowland K, Linda S Bamber, and Senyo Tse, 1989, Timeliness of financial reporting, the firm size effect, and stock price reactions to annual earnings announcements, Contemporary Accounting Research 5, 526-552.

Ball, Ray, and Stephen P Kothari, 1991, Security returns around earnings announcements, Accounting Review 718-738.

Barber, Brad M, Emmanuel T De George, Reuven Lehavy, and Brett Trueman, 2013, The earnings announcement premium around the globe, Journal of Financial Economics 108, 118-138.

Barber, Brad M, and Terrance Odean, 2008, All that glitters: The effect of attention and news on the buying behavior of individual and institutional investors, The review of financial studies 21, 785-818.

Beaver, William H, 1968, The information content of annual earnings announcements, Journal of accounting research 67-92.

Ben-Rephael, Azi, Bruce I Carlin, Zhi Da, and Ryan D Israelsen, 2019, Information consumption and asset pricing, Available at SSRN: https://ssrn.com/abstract=3002339 or http://dx.doi.org/10.2139/ssrn.3002339.

Black, Fischer, Michael C Jensen, and Myron Scholes, 1972, The capital asset pricing model: Some empirical tests, Studies in the theory of capital markets 81, 79-121.

Campbell, John Y, Stefano Giglio, Christopher Polk, and Robert Turley, 2018, An intertemporal capm with stochastic volatility, Journal of Financial Economics 128, 207-233.

Campbell, John Y, Christopher Polk, and Tuomo Vuolteenaho, 2010, Growth or glamour? Fundamentals and systematic risk in stock returns, The Review of Financial Studies 23, 305-344.

Campbell, John Y, and Tuomo Vuolteenaho, 2004, Bad beta, good beta, American Economic Review 94, 1249-1275.

Chambers, Anne E, and Stephen H Penman, 1984, Timeliness of reporting and the stock price reaction to earnings announcements, Journal of accounting research 21-47.

Chen, Linda H, George J Jiang, and Kevin X Zhu, 2018, Total attention: The effect of macroeconomic news on market reaction to earnings news, Journal of Banking \& Finance 97, 142-156.

Cohen, Randolph B., Christopher Polk, and Tuomo Vuolteenaho, 2005, Money illusion in the stock market: The modigliani-cohn hypothesis, The Quarterly Journal of Economics 120, 639-668.

Da, Zhi, and Mitchell Craig Warachka, 2009, Cashflow risk, systematic earnings revisions, and the cross-section of stock returns, Journal of Financial Economics 94, 448-468.

DellaVigna, Stefano, and Joshua M Pollet, 2009, Investor inattention and friday earnings announcements, The Journal of Finance 64, 709-749.

Dimson, Elroy, 1979, Risk measurement when shares are subject to infrequent trading, Journal of Financial Economics 7, 197-226.

Fama, Eugene F, and Kenneth R French, 1992, The cross - section of expected stock returns, the Journal of Finance 47, 427-465. 
Fama, Eugene F, and Kenneth R French, 1993, Common risk factors in the returns on stocks and bonds, Journal of financial economics 33, 3-56.

Fama, Eugene F, and Kenneth R French, 2008, Dissecting anomalies, The Journal of Finance 63, 1653-1678.

Fama, Eugene F., and Kenneth R. French, 2015, A five-factor asset pricing model, Journal of Financial Economics 116, 1-22.

Foster, George, 1981, Intra-industry information transfers associated with earnings releases, Journal of accounting and economics 3, 201-232.

Frazzini, Andrea, and Owen Lamont, 2007, The earnings announcement premium and trading volume, NBER working paper.

Frazzini, Andrea, and Lasse Heje Pedersen, 2014, Betting against beta, Journal of Financial Economics 111, 1-25.

Freeman, Robert, and Senyo Tse, 1992, An earnings prediction approach to examining intercompany information transfers, Journal of Accounting and Economics 15, 509-523.

Gervais, Simon, Ron Kaniel, and Dan H Mingelgrin, 2001, The high - volume return premium, The Journal of Finance 56, 877-919.

Hendershott, Terrence, Dmitry Livdan, and Dominik Rösch, 2018, Asset pricing: A tale of night and day, Available at SSRN: https://ssrn.com/abstract=3117663 or http://dx.doi.org/10.2139/ssrn.3117663.

Hirshleifer, David, Sonya Seongyeon Lim, and Siew Hong Teoh, 2009, Driven to distraction: Extraneous events and underreaction to earnings news, The Journal of Finance 64, 22892325.

Hirshleifer, David, and Siew Hong Teoh, 2003, Limited attention, information disclosure, and financial reporting, Journal of accounting and economics 36, 337-386.

Lewellen, J., and S. Nagel, 2006, The conditional capm does not explain asset-pricing anomalies, Journal of Financial Economics 82, 289-314.

Ma, Qingzhong, David A Whidbee, and Wei Zhang, 2019, Acquirer reference prices and acquisition performance, Journal of Financial Economics 132, 175-199.

Patton, Andrew J, and Michela Verardo, 2012, Does beta move with news? Firm-specific information flows and learning about profitability, The Review of Financial Studies 25, 2789-2839.

Polk, C., S. Thompson, and T. Vuolteenaho, 2006, Cross-sectional forecasts of the equity premium, Journal of Financial Economics 81, 101-141.

Reinganum, Marc R, 1981, A new empirical perspective on the capm, Journal of financial and quantitative analysis 16, 439-462.

Robichek, Alexander A, and Stewart C Myers, 1966, Conceptual problems in the use of risk adjusted discount rates, The Journal of Finance 21, 727-730.

Savor, Pavel, and Mungo Wilson, 2014, Asset pricing: A tale of two days, Journal of Financial Economics 113, 171-201.

Savor, Pavel, and Mungo Wilson, 2016, Earnings announcements and systematic risk, The Journal of Finance 71, 83-138.

So, Eric C, and Sean Wang, 2014, News-driven return reversals: Liquidity provision ahead of earnings announcements, Journal of Financial Economics 114, 20-35.

Tinic, Seha M, and Richard R West, 1984, Risk and return: Janaury vs. The rest of the year, Journal of Financial Economics 13, 561-574. 
Zhang, X Frank, 2006, Information uncertainty and stock returns, The Journal of Finance 61, 105-137. 
Table 1 Summary Statistics

This table reports time series average of monthly cross-sectional statistics of firm characteristics. LNSIZE and LNBM are the natural log of market capitalization and the natural log of book-to-market ratio as defined in Fama and French (2008). MOM is momentum calculated as skip 1-month lagged 11-month cumulative returns. IVOL is idiosyncratic volatility in percentage relative to Fama-French three-factor model estimated based on daily returns over previous month. ILLIQ is Amihud (2002) illiquidity ratio pre-multiplied by $1,000,000$ based on daily returns over previous three months. LRET is lagged monthly return. LEV is leverage ratio calculated as total debt divided by the market value of the firm. IO is institutional ownership based on the most recent quarter. $\mathrm{COV}$ is analyst coverage defined as the number of analysts following the firm in the recent quarter. LSUE is lagged earnings surprise in the recent quarter based on seasonal random walk model. $\mathrm{N}$ denotes average number of observation of each variable. The sample period is from January 1982 to December 2017.

\begin{tabular}{ccccccc}
\hline Variable & $\mathrm{N}$ & Mean & St.Dev & $25 \%$ & Median & $75 \%$ \\
\hline LNSIZE & 3,556 & 5.610 & 1.903 & 4.192 & 5.504 & 6.914 \\
LNBM & 3,455 & -0.533 & 0.809 & -0.979 & -0.440 & -0.008 \\
MOM & 3,557 & 0.139 & 0.533 & -0.144 & 0.074 & 0.313 \\
IVOL & 3,557 & 2.729 & 2.193 & 1.408 & 2.154 & 3.364 \\
ILLIQ & 3,529 & 2.347 & 13.518 & 0.008 & 0.074 & 0.723 \\
LRET & 3,557 & 0.012 & 0.137 & -0.055 & 0.005 & 0.068 \\
LEV & 3,532 & 0.270 & 0.239 & 0.053 & 0.217 & 0.433 \\
IO & 3,557 & 0.355 & 0.284 & 0.072 & 0.336 & 0.602 \\
COV & 3,557 & 3.798 & 5.181 & 0.313 & 1.854 & 5.184 \\
LSUE & 3,517 & -0.002 & 0.102 & -0.008 & 0.001 & 0.007 \\
\hline
\end{tabular}




\section{Table 2 Earnings Beta, CAPM Beta and Alternative Cash-flow Risk Measures}

Panel A reports the time series average of monthly cross-sectional statistics of earnings beta, earnings beta Dimson (1979) approach, CAPM beta, VAR cash-flow beta and quarterly earnings beta for the full sample. Panels B, C and D report the statistics for size, B/M, and long-term return subsamples. Each month, stocks are divided into small and big, high and low, and long-term loser and winner based on the median of size, book-to-market ratio and skipping 1-year past 3-year cumulative return, respectively. Panel E reports the time series average of cross-sectional correlation. Earnings beta $\left(\beta^{E A}\right)$ for each firm is estimated from: $R_{i, t}=\alpha_{i}+\left(\beta_{i}+\beta_{i}^{E A} d^{E A}\right) R_{m, t}+\varepsilon_{i t}$ based on daily returns over 3-year rolling window with at least 2 years of observations. Dummy variable $d^{E A}=1$ at announcement window [-1,0,1] and zero otherwise. $R_{i t}$ is firm i's return in excess of risk free rate. $R_{m t}$ is excess market return. Earnings beta Dimson (1979) approach $\left(\beta^{E A(D)}\right)$ is estimated from: $R_{i, t}=\alpha_{i}+\sum_{k=-1}^{1}\left[\left(\beta_{i, k}+\beta_{i, k}^{E A} d^{E A}\right) R_{m, t+k}\right]+\varepsilon_{i, t}$, where $\beta^{E A(D)}=\sum_{k=-1}^{1} \beta_{i, k}^{E A}$. CAPM beta $\left(\beta^{C A P M}\right)$ is estimated based on daily returns over 3-year rolling window. VAR cash-flow beta $\left(\beta^{C F(V A R)}\right)$ is estimated based on monthly returns over 3-year rolling window. VAR cash-flow news and discount-rate news components are obtained from Campbell, Giglio, Polk and Turley (2018) and are available over the sample period from 1980 to 2011. Quarterly earnings beta $\left(\beta^{Q E}\right)$ is estimated based on quarterly earnings growth over 5-year rolling window. The sample period is from January 1980 to December 2017.

Panel A: Full Sample

\begin{tabular}{ccccccc}
\hline Variable & $\mathrm{N}$ & Mean & St.Dev & $25 \%$ & Median & $75 \%$ \\
\hline$\beta^{E A}$ & 3,557 & 0.031 & 0.958 & -0.437 & 0.012 & 0.492 \\
$\beta^{E A(D)}$ & 3,551 & 0.058 & 1.625 & -0.742 & 0.033 & 0.837 \\
$\beta^{\text {CAPM }}$ & 3,557 & 0.819 & 0.477 & 0.478 & 0.784 & 1.110 \\
$\beta^{\text {CF(VAR) }}$ & 3,555 & 0.033 & 0.170 & -0.060 & 0.025 & 0.118 \\
$\beta^{Q E}$ & 3,528 & 1.275 & 11.715 & -0.572 & 0.279 & 1.768 \\
\hline Panel B: Size subsamples & & & & & & \\
\hline Small & & & & & & \\
$\beta^{E A}$ & 1,778 & 0.032 & 1.115 & -0.548 & 0.015 & 0.600 \\
$\beta^{E A(D)}$ & 1,773 & 0.065 & 1.876 & -0.907 & 0.039 & 1.013 \\
$\beta^{C A P M}$ & 1,778 & 0.676 & 0.467 & 0.312 & 0.621 & 0.976 \\
$\beta^{C F(V A R)}$ & 1,777 & 0.048 & 0.193 & -0.060 & 0.041 & 0.149 \\
$\beta^{Q E}$ & 1,764 & 1.532 & 13.869 & -1.049 & 0.367 & 2.518 \\
Big & & & & & & \\
$\beta^{E A}$ & 1,778 & 0.030 & 0.768 & -0.360 & 0.010 & 0.412 \\
$\beta^{E A(D)}$ & 1,778 & 0.051 & 1.324 & -0.624 & 0.028 & 0.701 \\
$\beta^{C A P M}$ & 1,778 & 0.962 & 0.433 & 0.645 & 0.906 & 1.215 \\
$\beta^{C F(V A R)}$ & 1,777 & 0.017 & 0.138 & -0.059 & 0.013 & 0.090 \\
$\beta^{Q E}$ & 1,764 & 1.017 & 8.853 & -0.311 & 0.231 & 1.236 \\
\hline
\end{tabular}


Panel C: B/M subsamples

\begin{tabular}{|c|c|c|c|c|c|c|}
\hline Variable & $\mathrm{N}$ & Mean & St.Dev & $25 \%$ & Median & $75 \%$ \\
\hline \multicolumn{7}{|l|}{ High } \\
\hline$\beta^{E A}$ & 1,728 & 0.026 & 0.944 & -0.418 & 0.006 & 0.458 \\
\hline$\beta^{E A(D)}$ & 1,725 & 0.048 & 1.582 & -0.707 & 0.027 & 0.780 \\
\hline$\beta^{C A P M}$ & 1,728 & 0.701 & 0.449 & 0.357 & 0.668 & 0.986 \\
\hline$\beta^{C F(V A R)}$ & 1,729 & 0.030 & 0.157 & -0.057 & 0.023 & 0.111 \\
\hline$\beta^{Q E}$ & 1,717 & 1.592 & 11.966 & -0.709 & 0.421 & 2.403 \\
\hline \multicolumn{7}{|l|}{ Low } \\
\hline$\beta^{E A}$ & 1,727 & 0.038 & 0.956 & -0.450 & 0.019 & 0.522 \\
\hline$\beta^{E A(D)}$ & 1,724 & 0.070 & 1.640 & -0.766 & 0.041 & 0.890 \\
\hline$\beta^{C A P M}$ & 1,727 & 0.932 & 0.463 & 0.609 & 0.893 & 1.216 \\
\hline$\beta^{C F(V A R)}$ & 1,728 & 0.034 & 0.175 & -0.063 & 0.027 & 0.122 \\
\hline$\beta^{Q E}$ & 1,711 & 0.793 & 9.177 & -0.436 & 0.198 & 1.217 \\
\hline \multicolumn{7}{|c|}{ Panel D: Long-term return subsamples } \\
\hline \multicolumn{7}{|l|}{ Loser } \\
\hline$\beta^{E A}$ & 1,732 & 0.017 & 1.044 & -0.508 & -0.001 & 0.534 \\
\hline$\beta^{E A(D)}$ & 1,728 & 0.026 & 1.764 & -0.869 & 0.007 & 0.899 \\
\hline$\beta^{C A P M}$ & 1,732 & 0.794 & 0.473 & 0.449 & 0.769 & 1.091 \\
\hline$\beta^{C F(V A R)}$ & 1,734 & 0.032 & 0.174 & -0.064 & 0.025 & 0.122 \\
\hline$\beta^{Q E}$ & 1,728 & 1.631 & 13.285 & -0.750 & 0.402 & 2.412 \\
\hline \multicolumn{7}{|l|}{ Winner } \\
\hline$\beta^{E A}$ & 1,733 & 0.043 & 0.842 & -0.376 & 0.022 & 0.451 \\
\hline$\beta^{E A(D)}$ & 1,731 & 0.086 & 1.437 & -0.632 & 0.052 & 0.774 \\
\hline$\beta^{C A P M}$ & 1,733 & 0.835 & 0.459 & 0.505 & 0.798 & 1.123 \\
\hline$\beta^{C F(V A R)}$ & 1,734 & 0.034 & 0.158 & -0.055 & 0.025 & 0.112 \\
\hline$\beta^{Q E}$ & 1,731 & 0.941 & 8.937 & -0.453 & 0.220 & 1.328 \\
\hline \multicolumn{7}{|c|}{ Panel E: Cross-sectional correlation } \\
\hline Variable & $\beta^{E A}$ & $\beta^{E A(D)}$ & $\beta^{C A P M}$ & $\beta^{C F(V A R)}$ & $\beta^{Q E}$ & \\
\hline$\beta^{E A}$ & 1 & $0.527 * * *$ & $0.036^{* * *}$ & -0.003 & 0.001 & \\
\hline$\beta^{E A(D)}$ & & 1 & $0.021 * * *$ & -0.008 & 0.002 & \\
\hline$\beta^{C A P M}$ & & & 1 & $-0.047 * *$ & $0.040 * * *$ & \\
\hline$\beta^{C F(V A R)}$ & & & & 1 & $-0.019 * * *$ & \\
\hline$\beta^{Q E}$ & & & & & 1 & \\
\hline
\end{tabular}




\section{Table 3 Average Returns of Earnings beta Portfolios}

Each month, quintile portfolios are formed based on earnings beta at the end of month t. Quintile Q1 (5) consists of stocks with the lowest (highest) earnings betas. The table reports average returns and FamaFrench three-factor and five-factor alphas in month $t+1$ for quintile portfolios sorted on earnings beta. The table also reports return and alpha spreads between the highest and lowest quintiles. The t-statistics are based on Newey-West standard errors with three lags. *, **, and *** denote significance at the $10 \%, 5 \%$, and $1 \%$ levels, respectively.

\begin{tabular}{cccccccc}
\hline Quintile & \multicolumn{3}{c}{ Equal-weighted return } & & \multicolumn{3}{c}{ Value-weighted return } \\
\cline { 2 - 3 } \cline { 6 - 7 } & Return & FF3 Alpha & FF5 Alpha & & Return & FF3 Alpha & FF5 Alpha \\
\hline Q1 & 1.25 & 0.03 & 0.21 & & 1.13 & 0.01 & 0.06 \\
Q2 & 1.18 & 0.04 & 0.04 & & 1.03 & 0.01 & -0.06 \\
Q3 & 1.24 & 0.14 & 0.12 & & 1.05 & 0.05 & -0.03 \\
Q4 & 1.27 & 0.13 & 0.14 & & 0.97 & -0.04 & -0.07 \\
Q5 & 1.28 & 0.08 & 0.27 & & 1.10 & 0.03 & 0.21 \\
Q5-Q1 & 0.04 & 0.05 & 0.07 & & -0.03 & 0.02 & 0.15 \\
(t-Stat) & $(0.84)$ & $(1.08)$ & $(1.29)$ & & $(-0.31)$ & $(0.23)$ & $(1.53)$ \\
\hline
\end{tabular}




\section{Table 4 Average Returns of Earnings beta Portfolios Returns: Firms with and without}

Earnings Announcements

In Panel A, quintile portfolios are formed separately for announcing and non-announcing firms in month $\mathrm{t}+1$ based on earnings beta in month t. Quintile Q1 (5) consists of stocks with the lowest (highest) earnings betas. The panel reports average returns and Fama-French three-factor and five-factor alphas in month $t+1$ for quintile portfolios. In Panel B, quintile portfolios are formed in month $t+1, t+2$ and $t+3$ based on earnings beta in month $t$. The panel reports average portfolios returns over months $t+1$ to $t+3$. The table also reports return and alpha spreads between the highest and lowest quintiles. The t-statistics are based on NeweyWest standard errors with three lags. *, **, and *** denote significance at the $10 \%, 5 \%$, and $1 \%$ levels, respectively.

Panel A: Portfolios Returns for Month $t+1$

\begin{tabular}{|c|c|c|c|c|c|c|}
\hline \multirow[t]{2}{*}{ Quintile } & \multicolumn{3}{|c|}{ Equal-weighted return } & \multicolumn{3}{|c|}{ Value-weighted return } \\
\hline & Return & FF3 Alpha & FF5 Alpha & Return & FF3 Alpha & FF5 Alpha \\
\hline \multicolumn{7}{|c|}{ Firms with Earnings Announcements } \\
\hline Q1 & 1.35 & 0.15 & 0.30 & 1.18 & 0.08 & 0.14 \\
\hline Q2 & 1.40 & 0.28 & 0.25 & 1.27 & 0.23 & 0.12 \\
\hline Q3 & 1.50 & 0.42 & 0.39 & 1.47 & 0.46 & 0.39 \\
\hline Q4 & 1.52 & 0.38 & 0.32 & 1.33 & 0.29 & 0.20 \\
\hline Q5 & 1.64 & 0.43 & 0.59 & 1.79 & 0.74 & 0.95 \\
\hline $\begin{array}{l}\text { Q5-Q1 } \\
\text { (t-Stat) }\end{array}$ & $\begin{array}{c}0.28 * * * \\
(2.93)\end{array}$ & $\begin{array}{c}0.28 * * * \\
(2.93)\end{array}$ & $\begin{array}{c}0.29 * * * \\
(2.70)\end{array}$ & $\begin{array}{c}0.62 * * * \\
(2.89)\end{array}$ & $\begin{array}{c}0.66 * * * \\
(2.95)\end{array}$ & $\begin{array}{c}0.81^{* * *} \\
(3.19)\end{array}$ \\
\hline \multicolumn{7}{|c|}{ Firms without Earnings Announcements } \\
\hline Q1 & 1.20 & -0.02 & 0.18 & 0.95 & -0.18 & -0.15 \\
\hline Q2 & 1.06 & -0.08 & -0.06 & 0.98 & -0.07 & -0.13 \\
\hline Q3 & 1.10 & -0.01 & -0.02 & 0.90 & -0.11 & -0.19 \\
\hline Q4 & 1.14 & 0.01 & 0.03 & 0.79 & -0.23 & -0.28 \\
\hline Q5 & 1.17 & -0.03 & 0.17 & 0.90 & -0.19 & -0.02 \\
\hline $\begin{array}{l}\text { Q5-Q1 } \\
\text { (t-Stat) }\end{array}$ & $\begin{array}{c}-0.03 \\
(-0.47)\end{array}$ & $\begin{array}{c}-0.01 \\
(-0.19)\end{array}$ & $\begin{array}{l}-0.00 \\
(-0.00)\end{array}$ & $\begin{array}{c}-0.05 \\
(-0.46)\end{array}$ & $\begin{array}{l}-0.01 \\
(-0.06)\end{array}$ & $\begin{array}{c}0.12 \\
(1.14)\end{array}$ \\
\hline \multicolumn{7}{|c|}{ Panel B: Average Portfolios Returns over Month $t+1$ to Month $t+3$} \\
\hline \multirow[t]{2}{*}{ Quintile } & \multicolumn{3}{|c|}{ Equal-weighted return } & \multicolumn{3}{|c|}{ Value-weighted return } \\
\hline & Return & FF3 Alpha & FF5 Alpha & Return & FF3 Alpha & FF5 Alpha \\
\hline \multicolumn{7}{|c|}{ Firms with Earnings Announcements } \\
\hline Q1 & 1.40 & 0.10 & 0.22 & 1.15 & 0.03 & 0.10 \\
\hline Q2 & 1.36 & 0.14 & 0.10 & 1.34 & 0.28 & 0.16 \\
\hline Q3 & 1.54 & 0.40 & 0.33 & 1.47 & 0.49 & 0.48 \\
\hline Q4 & 1.54 & 0.37 & 0.28 & 1.35 & 0.31 & 0.22 \\
\hline Q5 & 1.64 & 0.39 & 0.52 & 1.78 & 0.78 & 0.94 \\
\hline $\begin{array}{l}\text { Q5-Q1 } \\
\text { (t-Stat) }\end{array}$ & $\begin{array}{c}0.24 * * * \\
(2.83)\end{array}$ & $\begin{array}{c}0.29 * * * \\
(3.24)\end{array}$ & $\begin{array}{c}0.30 * * * \\
(2.96)\end{array}$ & $\begin{array}{c}0.63 * * * \\
(3.39)\end{array}$ & $\begin{array}{c}0.76^{* * * *} \\
(3.62)\end{array}$ & $\begin{array}{c}0.84^{* * *} \\
(3.75)\end{array}$ \\
\hline \multicolumn{7}{|c|}{ Firms without Earnings Announcements } \\
\hline Q1 & 1.22 & -0.06 & 0.10 & 0.98 & -0.17 & -0.12 \\
\hline Q2 & 1.08 & -0.11 & -0.12 & 0.98 & -0.08 & -0.16 \\
\hline Q3 & 1.10 & -0.03 & -0.07 & 0.92 & -0.10 & -0.20 \\
\hline Q4 & 1.16 & 0.00 & 0.00 & 0.79 & -0.23 & -0.28 \\
\hline Q5 & 1.18 & -0.07 & 0.11 & 0.93 & -0.16 & 0.02 \\
\hline $\begin{array}{l}\text { Q5-Q1 } \\
\text { (t-Stat) }\end{array}$ & $\begin{array}{c}-0.04 \\
(-0.82)\end{array}$ & $\begin{array}{c}-0.01 \\
(-0.19)\end{array}$ & $\begin{array}{c}0.02 \\
(0.33)\end{array}$ & $\begin{array}{c}-0.05 \\
(-0.58)\end{array}$ & $\begin{array}{c}0.01 \\
(0.06)\end{array}$ & $\begin{array}{c}0.14 \\
(1.34)\end{array}$ \\
\hline
\end{tabular}




\section{Table 5 Persistence in Earnings beta}

Each month, quintile portfolios are formed separately for announcing and non-announcing firms based on earnings beta in month t. Quintile Q1 (5) consists of stocks with the lowest (highest) earnings betas. Panel A reports average returns and Fama-French three-factor and five-factor alphas over month $t+1$ to $1+6$. Panel $B$ reports average portfolios returns over month $t+1$ to $1+12$. The table also reports return and alpha spreads between the highest and lowest quintiles. The t-statistics are based on Newey-West standard errors with three lags. *, **, and *** denote significance at the $10 \%, 5 \%$, and $1 \%$ levels, respectively.

\begin{tabular}{|c|c|c|c|c|c|c|}
\hline \multirow[t]{2}{*}{ Quintile } & \multicolumn{3}{|c|}{ Equal-weighted return } & \multicolumn{3}{|c|}{ Value-weighted return } \\
\hline & Return & FF3 Alpha & FF5 Alpha & Return & FF3 Alpha & FF5 Alpha \\
\hline \multicolumn{7}{|c|}{ Firms with Earnings Announcements } \\
\hline Q1 & 1.45 & 0.11 & 0.20 & 1.30 & 0.21 & 0.28 \\
\hline Q2 & 1.35 & 0.11 & 0.04 & 1.33 & 0.27 & 0.12 \\
\hline Q3 & 1.56 & 0.36 & 0.29 & 1.45 & 0.43 & 0.46 \\
\hline Q4 & 1.55 & 0.38 & 0.29 & 1.39 & 0.35 & 0.18 \\
\hline Q5 & 1.64 & 0.38 & 0.48 & 1.78 & 0.84 & 1.03 \\
\hline $\begin{array}{l}\text { Q5-Q1 } \\
\text { (t-Stat) }\end{array}$ & $\begin{array}{c}0.19 * * * \\
(2.84)\end{array}$ & $\begin{array}{c}0.27 * * * \\
(3.97)\end{array}$ & $\begin{array}{c}0.29 * * * \\
(3.55)\end{array}$ & $\begin{array}{c}0.48 * * * \\
(3.05)\end{array}$ & $\begin{array}{c}0.64 * * * \\
(3.01)\end{array}$ & $\begin{array}{c}0.75^{* * *} \\
(3.48)\end{array}$ \\
\hline \multicolumn{7}{|c|}{ Firms without Earnings Announcements } \\
\hline Q1 & 1.22 & -0.08 & 0.03 & 1.01 & -0.16 & -0.11 \\
\hline Q2 & 1.12 & -0.07 & -0.12 & 0.97 & -0.08 & -0.14 \\
\hline Q3 & 1.10 & -0.05 & -0.10 & 0.92 & -0.10 & -0.20 \\
\hline Q4 & 1.17 & 0.02 & 0.00 & 0.81 & -0.23 & -0.29 \\
\hline Q5 & 1.19 & -0.06 & 0.10 & 0.94 & -0.15 & 0.09 \\
\hline $\begin{array}{l}\text { Q5-Q1 } \\
\text { (t-Stat) }\end{array}$ & $\begin{array}{c}-0.04 \\
(-0.89) \\
\end{array}$ & $\begin{array}{c}0.01 \\
(0.33) \\
\end{array}$ & $\begin{array}{c}0.07 \\
(1.51) \\
\end{array}$ & $\begin{array}{c}-0.08 \\
(-0.85) \\
\end{array}$ & $\begin{array}{c}0.01 \\
(0.09) \\
\end{array}$ & $\begin{array}{l}0.20^{*} \\
(1.89) \\
\end{array}$ \\
\hline \multicolumn{7}{|c|}{ Panel B: Average Portfolios Returns from Month $t+1$ to Month $t+12$} \\
\hline \multirow[t]{2}{*}{ Quintile } & \multicolumn{3}{|c|}{ Equal-weighted return } & \multicolumn{3}{|c|}{ Value-weighted return } \\
\hline & Return & FF3 Alpha & FF5 Alpha & Return & FF3 Alpha & FF5 Alpha \\
\hline \multicolumn{7}{|c|}{ Firms with Earnings Announcements } \\
\hline Q1 & 1.49 & 0.18 & 0.20 & 1.29 & 0.23 & 0.36 \\
\hline Q2 & 1.37 & 0.09 & -0.02 & 1.36 & 0.30 & 0.13 \\
\hline Q3 & 1.53 & 0.35 & 0.20 & 1.38 & 0.33 & 0.32 \\
\hline Q4 & 1.57 & 0.40 & 0.21 & 1.41 & 0.33 & 0.20 \\
\hline Q5 & 1.62 & 0.42 & 0.41 & 1.84 & 0.97 & 1.18 \\
\hline $\begin{array}{l}\text { Q5-Q1 } \\
\text { (t-Stat) }\end{array}$ & $\begin{array}{c}0.13^{* * * *} \\
(2.62)\end{array}$ & $\begin{array}{c}0.24 * * * \\
(4.73)\end{array}$ & $\begin{array}{c}0.21^{* * *} \\
(3.46)\end{array}$ & $\begin{array}{c}0.56 * * * \\
(4.73)\end{array}$ & $\begin{array}{c}0.74 * * * \\
(5.08)\end{array}$ & $\begin{array}{c}0.82 * * * \\
(4.57)\end{array}$ \\
\hline \multicolumn{7}{|c|}{ Firms without Earnings Announcements } \\
\hline Q1 & 1.24 & -0.02 & -0.02 & 1.04 & -0.09 & -0.07 \\
\hline Q2 & 1.16 & 0.00 & -0.10 & 0.97 & -0.08 & -0.16 \\
\hline Q3 & 1.11 & -0.01 & -0.15 & 0.91 & -0.11 & -0.22 \\
\hline Q4 & 1.17 & 0.01 & -0.05 & 0.84 & -0.18 & -0.30 \\
\hline Q5 & 1.19 & -0.05 & 0.02 & 0.91 & -0.13 & 0.17 \\
\hline $\begin{array}{l}\text { Q5-Q1 } \\
\text { (t-Stat) }\end{array}$ & $\begin{array}{c}-0.05^{* *} \\
(-1.99) \\
\end{array}$ & $\begin{array}{c}-0.03 \\
(-0.85)\end{array}$ & $\begin{array}{c}0.04 \\
(1.02)\end{array}$ & $\begin{array}{l}-0.13 * \\
(-1.91)\end{array}$ & $\begin{array}{c}-0.04 \\
(-0.50)\end{array}$ & $\begin{array}{l}0.23 * * \\
(2.37)\end{array}$ \\
\hline
\end{tabular}




\section{Table 6 Earnings beta and Stock Returns: Multivariate Regressions}

Panel A reports average estimates of Fama-MacBeth cross-sectional regressions of monthly stock returns on earnings beta interacting with announcement dummy, and other control variables. Panel B reports estimates of panel regressions with time fixed effects. Earnings beta $\left(\beta^{E A}\right)$ is estimated based on daily returns over the 3-year rolling window. The announcement dummy is defined as $d^{A N N}=1$ if a firm has earnings announcement in the return month. In model (3) and (4), $d^{A N N}=1$ if a firm has either earnings or M\&A announcement in the return month. $d^{N A N N}$ is the dummy for non-announcing firms, defined as 1$d^{A N N}$. Control variables include CAPM beta $\left(\beta^{C A P M}\right)$, the natural log of market capitalization (LNSIZE), the natural log of book-to-market ratio (LNBM), momentum (MOM), idiosyncratic volatility (IVOL), illiquidity ratio (ILLIQ), lagged returns (LRET), leverage ratio (LEV), institutional ownership (IO), analyst coverage (COV) and lagged standardized earnings surprise (LSUE) estimated from a seasonal random walk model. *, **, and $* * *$ denote significance at the $10 \%$, 5\%, and $1 \%$ levels, respectively. For Fama-MacBeth regressions, the t-statistics are based on Newey-West standard errors with 12 lags. For panel regressions, the t-statistics are based on standard errors clustered by time.

Panel A: Fama-MacBeth Regressions

\begin{tabular}{|c|c|c|c|c|}
\hline \multirow[b]{3}{*}{$\beta^{E A *} d^{A N N}$} & \multicolumn{2}{|c|}{ Earnings Announcement } & \multicolumn{2}{|c|}{ Earnings or M\&A Announcement } \\
\hline & $(1)$ & (2) & (3) & $(4)$ \\
\hline & $\begin{array}{c}0.093^{* * *} \\
(2.61)\end{array}$ & $\begin{array}{c}0.076^{* * *} \\
(2.08)\end{array}$ & $\begin{array}{c}0.095 * * * \\
(2.85)\end{array}$ & $\begin{array}{c}0.082 * * \\
(2.40)\end{array}$ \\
\hline$\beta^{E A *} d^{N A N N}$ & $\begin{array}{l}-0.002 \\
(-0.12)\end{array}$ & $\begin{array}{l}-0.004 \\
(-0.23)\end{array}$ & $\begin{array}{l}-0.003 \\
(-0.20)\end{array}$ & $\begin{array}{l}-0.006 \\
(-0.32)\end{array}$ \\
\hline$d^{A N N}$ & $\begin{array}{c}0.347^{* * *} \\
(6.14)\end{array}$ & $\begin{array}{c}0.399 * * * \\
(7.12)\end{array}$ & $\begin{array}{c}0.396 * * * \\
(6.91)\end{array}$ & $\begin{array}{c}0.447 * * * \\
(7.82)\end{array}$ \\
\hline$\beta^{C A P M}$ & & $\begin{array}{l}0.022 \\
(0.10)\end{array}$ & & $\begin{array}{l}0.022 \\
(0.09)\end{array}$ \\
\hline LNSIZE & & $\begin{array}{c}-0.208^{* *} \\
(-2.40)\end{array}$ & & $\begin{array}{c}-0.208 * * \\
(-2.41)\end{array}$ \\
\hline LNBM & & $\begin{array}{c}0.203 * * * \\
(4.14)\end{array}$ & & $\begin{array}{c}0.203 * * * \\
(4.15)\end{array}$ \\
\hline MOM & & $\begin{array}{l}0.330 \\
(1.55)\end{array}$ & & $\begin{array}{l}0.329 \\
(1.55)\end{array}$ \\
\hline IVOL & & $\begin{array}{c}-0.191 * * \\
(-2.07)\end{array}$ & & $\begin{array}{c}-0.189 * * \\
(-2.05)\end{array}$ \\
\hline ILLIQ & & $\begin{array}{c}0.036 * * * \\
(4.02)\end{array}$ & & $\begin{array}{c}0.036^{* * *} \\
(4.02)\end{array}$ \\
\hline LRET & & $\begin{array}{c}-3.974 * * * \\
(-9.18)\end{array}$ & & $\begin{array}{c}-3.975 * * * \\
(-9.19)\end{array}$ \\
\hline LEV & & $\begin{array}{c}-0.492^{*} \\
(-1.94)\end{array}$ & & $\begin{array}{c}-0.492 * \\
(-1.95)\end{array}$ \\
\hline IO & & $\begin{array}{l}0.062 \\
(1.47)\end{array}$ & & $\begin{array}{l}0.062 \\
(1.47)\end{array}$ \\
\hline $\mathrm{COV}$ & & $\begin{array}{l}0.029 \\
(1.09)\end{array}$ & & $\begin{array}{l}0.029 \\
(1.11)\end{array}$ \\
\hline LSUE & & $\begin{array}{c}0.268^{* * *} \\
(6.06)\end{array}$ & & $\begin{array}{c}0.268 * * * \\
(6.06)\end{array}$ \\
\hline $\mathrm{N}$ & $1,536,746$ & $1,456,663$ & $1,536,746$ & $1,456,663$ \\
\hline Adj. $R^{2}$ & 0.002 & 0.062 & 0.002 & 0.062 \\
\hline
\end{tabular}




\begin{tabular}{|c|c|c|c|c|}
\hline \multirow[b]{3}{*}{$\beta^{E A *} d^{A N N}$} & \multicolumn{2}{|c|}{ Earnings Announcement } & \multicolumn{2}{|c|}{ Earnings or M\&A Announcement } \\
\hline & $(1)$ & $(2)$ & (3) & $(4)$ \\
\hline & $\begin{array}{c}0.070^{* *} \\
(2.49)\end{array}$ & $\begin{array}{c}0.061^{* *} \\
(2.16)\end{array}$ & $\begin{array}{c}0.073^{* * *} \\
(2.61)\end{array}$ & $\begin{array}{c}0.064^{* *} \\
(2.27)\end{array}$ \\
\hline$\beta^{E A *} d^{N A N N}$ & $\begin{array}{l}-0.001 \\
(-0.05)\end{array}$ & $\begin{array}{l}-0.006 \\
(-0.30)\end{array}$ & $\begin{array}{l}-0.003 \\
(-0.14)\end{array}$ & $\begin{array}{l}-0.008 \\
(-0.39)\end{array}$ \\
\hline$d^{A N N}$ & $\begin{array}{c}0.290^{* * *} \\
(3.25)\end{array}$ & $\begin{array}{c}0.261^{* * *} \\
(3.14)\end{array}$ & $\begin{array}{c}0.330 * * * \\
(3.78)\end{array}$ & $\begin{array}{c}0.304^{* * *} \\
(3.78)\end{array}$ \\
\hline$\beta^{C A P M}$ & & $\begin{array}{l}0.021 \\
(0.07)\end{array}$ & & $\begin{array}{l}0.020 \\
(0.07)\end{array}$ \\
\hline LNSIZE & & $\begin{array}{c}-0.213^{* * * *} \\
(-2.76)\end{array}$ & & $\begin{array}{c}-0.214 * * * \\
(-2.78)\end{array}$ \\
\hline LNBM & & $\begin{array}{c}0.276 * * * \\
(3.94)\end{array}$ & & $\begin{array}{c}0.277 * * * \\
(3.95)\end{array}$ \\
\hline MOM & & $\begin{array}{l}0.245 \\
(1.05)\end{array}$ & & $\begin{array}{l}0.244 \\
(1.04)\end{array}$ \\
\hline IVOL & & $\begin{array}{l}-0.068 \\
(-0.43)\end{array}$ & & $\begin{array}{l}-0.066 \\
(-0.42)\end{array}$ \\
\hline ILLIQ & & $\begin{array}{c}0.010 * * \\
(2.57)\end{array}$ & & $\begin{array}{c}0.010 * * \\
(2.57)\end{array}$ \\
\hline LRET & & $\begin{array}{c}-3.386^{* * * *} \\
(-3.26)\end{array}$ & & $\begin{array}{c}-3.387 * * * \\
(-3.26)\end{array}$ \\
\hline LEV & & $\begin{array}{c}-0.440 * \\
(-1.81)\end{array}$ & & $\begin{array}{c}-0.441^{*} \\
(-1.81)\end{array}$ \\
\hline IO & & $\begin{array}{l}0.056 \\
(1.19)\end{array}$ & & $\begin{array}{l}0.056 \\
(1.19)\end{array}$ \\
\hline $\mathrm{COV}$ & & $\begin{array}{c}0.072^{* *} \\
(2.56)\end{array}$ & & $\begin{array}{c}0.073^{* *} \\
(2.58)\end{array}$ \\
\hline LSUE & & $\begin{array}{c}0.222 * * * \\
(3.59)\end{array}$ & & $\begin{array}{c}0.222 * * * \\
(3.59)\end{array}$ \\
\hline $\mathrm{N}$ & $1,536,746$ & $1,456,663$ & $1,536,746$ & $1,456,663$ \\
\hline Adj. $R^{2}$ & 0.114 & 0.120 & 0.114 & 0.120 \\
\hline
\end{tabular}




\section{Table 7 VAR Cash-flow Beta}

The table reports average estimates of Fama-MacBeth cross-sectional regressions of monthly stock returns on VAR cash-flow beta and other variables. VAR cash-flow beta $\left(\beta^{C F(V A R)}\right)$ and VAR discount-rate beta $\left(\beta^{D R(V A R)}\right)$ are estimated using cash-flow news and discount-rate news components from 1980 to 2011, obtained from Campbell, Giglio, Polk and Turley (2018). The announcement dummy is defined as $d^{A N N}=1$ if a firm has earnings announcement in the return month. $d^{N A N N}$ is the dummy for non-announcing firms, defined as $1-d^{A N N}$. Control variables are the same as those in Table 7. *, $* *$, and $* * *$ denote significance at the $10 \%, 5 \%$, and $1 \%$ levels, respectively. The t-statistics are based on Newey-West standard errors with 12 lags.

\begin{tabular}{|c|c|c|c|c|c|}
\hline & (1) & (2) & (3) & (4) & (5) \\
\hline$\beta^{E A *} d^{A N N}$ & & & & $\begin{array}{c}0.108 * * * \\
(2.70)\end{array}$ & $\begin{array}{c}0.095 * * \\
(2.43)\end{array}$ \\
\hline$\beta^{E A *} d^{N A N N}$ & & & & $\begin{array}{l}0.006 \\
(0.31)\end{array}$ & $\begin{array}{l}0.000 \\
(0.00)\end{array}$ \\
\hline$\beta^{C F(V A R)}$ & $\begin{array}{l}0.981 \\
(1.59)\end{array}$ & & & $\begin{array}{l}0.987 \\
(1.62)\end{array}$ & $\begin{array}{l}0.575 \\
(1.34)\end{array}$ \\
\hline$\beta^{C F(V A R) *} d^{A N N}$ & & $\begin{array}{l}0.812 \\
(1.17)\end{array}$ & $\begin{array}{l}0.475 \\
(1.11)\end{array}$ & & \\
\hline$\beta^{C F(V A R) * d^{N A N N}}$ & & $\begin{array}{l}0.980 \\
(1.57)\end{array}$ & $\begin{array}{l}0.496 \\
(1.08)\end{array}$ & & \\
\hline$d^{A N N}$ & & $\begin{array}{c}0.358 * * * \\
(5.70)\end{array}$ & $\begin{array}{c}0.457 * * * \\
(7.61)\end{array}$ & $\begin{array}{c}0.357 * * * \\
(5.67)\end{array}$ & $\begin{array}{c}0.448 * * * \\
(7.48)\end{array}$ \\
\hline$\beta^{D R(V A R)}$ & & & $\begin{array}{l}-0.089 \\
(-0.71)\end{array}$ & & $\begin{array}{l}-0.088 \\
(-0.71)\end{array}$ \\
\hline$\beta^{C A P M}$ & & & $\begin{array}{l}0.105 \\
(0.41)\end{array}$ & & $\begin{array}{l}0.104 \\
(0.40)\end{array}$ \\
\hline LNSIZE & & & $\begin{array}{c}-0.217^{* *} \\
(-2.39)\end{array}$ & & $\begin{array}{c}-0.219 * * \\
(-2.41)\end{array}$ \\
\hline LNBM & & & $\begin{array}{c}0.227 * * * \\
(4.36)\end{array}$ & & $\begin{array}{c}0.226 * * * \\
(4.36)\end{array}$ \\
\hline MOM & & & $\begin{array}{l}0.372 \\
(1.53)\end{array}$ & & $\begin{array}{l}0.372 \\
(1.54)\end{array}$ \\
\hline IVOL & & & $\begin{array}{c}-0.130 * \\
(-1.68)\end{array}$ & & $\begin{array}{c}-0.129 * \\
(-1.66)\end{array}$ \\
\hline ILLIQ & & & $\begin{array}{c}0.027 * * * \\
(4.03)\end{array}$ & & $\begin{array}{c}0.027 * * * \\
(4.02)\end{array}$ \\
\hline LRET & & & $\begin{array}{c}-4.725^{* * *} \\
(-11.04)\end{array}$ & & $\begin{array}{c}-4.714 * * * \\
(-11.03)\end{array}$ \\
\hline LEV & & & $\begin{array}{c}-0.596 * * \\
(-2.14)\end{array}$ & & $\begin{array}{c}-0.606 * * \\
(-2.16)\end{array}$ \\
\hline IO & & & $\begin{array}{l}0.019 \\
(0.45)\end{array}$ & & $\begin{array}{l}0.020 \\
(0.46)\end{array}$ \\
\hline $\mathrm{COV}$ & & & $\begin{array}{c}0.064 * * \\
(2.44)\end{array}$ & & $\begin{array}{c}0.064 * * \\
(2.45)\end{array}$ \\
\hline LSUE & & & $\begin{array}{c}0.213 * * * \\
(5.94)\end{array}$ & & $\begin{array}{c}0.212^{* * *} \\
(5.91)\end{array}$ \\
\hline $\mathrm{N}$ & $1,283,361$ & $1,283,361$ & $1,215,171$ & $1,283,361$ & $1,215,171$ \\
\hline Adj. $R^{2}$ & 0.005 & 0.007 & 0.066 & 0.007 & 0.066 \\
\hline
\end{tabular}




\section{Table 8 Quarterly Earnings Beta}

The table reports average estimates of Fama-MacBeth cross-sectional regressions of monthly stock returns on quarterly earnings beta and other variables. Quarterly earnings beta $\left(\beta^{Q E}\right)$ is estimated using earnings growth rate. The announcement dummy is defined as $d^{A N N}=1$ if a firm has earnings announcement in the return month. $d^{N A N N}$ is the dummy for non-announcing firms, defined as $1-d^{A N N}$. Control variables are the same as those in Table 7. *, **, and *** denote significance at the $10 \%, 5 \%$, and $1 \%$ levels, respectively. The t-statistics are based on Newey-West standard errors with 12 lags.

\begin{tabular}{|c|c|c|c|c|c|}
\hline & (1) & $(2)$ & (3) & (4) & (5) \\
\hline$\beta^{E A *} d^{A N N}$ & & & & $\begin{array}{c}0.097 * * * \\
(2.69)\end{array}$ & $\begin{array}{c}0.074 * * \\
(1.98)\end{array}$ \\
\hline$\beta^{E A *} d^{N A N N}$ & & & & $\begin{array}{l}-0.008 \\
(-0.46)\end{array}$ & $\begin{array}{l}-0.010 \\
(-0.60)\end{array}$ \\
\hline$\beta^{Q E}$ & $\begin{array}{l}-0.004 \\
(-0.84)\end{array}$ & & & $\begin{array}{l}-0.004 \\
(-0.80)\end{array}$ & $\begin{array}{c}-0.009 * \\
(-1.74)\end{array}$ \\
\hline$\beta^{Q E *} d^{A N N}$ & & $\begin{array}{l}0.002 \\
(0.19)\end{array}$ & $\begin{array}{l}-0.004 \\
(-0.48)\end{array}$ & & \\
\hline$\beta^{Q E *} d^{N A N N}$ & & $\begin{array}{l}-0.005 \\
(-1.15)\end{array}$ & $\begin{array}{c}-0.011 * * \\
(-2.13)\end{array}$ & & \\
\hline$d^{A N N}$ & & $\begin{array}{c}0.347^{* * *} \\
(6.20)\end{array}$ & $\begin{array}{c}0.394^{* * *} \\
(7.07)\end{array}$ & $\begin{array}{c}0.349 * * * \\
(6.15)\end{array}$ & $\begin{array}{c}0.400^{* * *} \\
(7.14)\end{array}$ \\
\hline$\beta^{C A P M}$ & & & $\begin{array}{l}0.026 \\
(0.11)\end{array}$ & & $\begin{array}{l}0.025 \\
(0.11)\end{array}$ \\
\hline LNSIZE & & & $\begin{array}{c}-0.192 * * \\
(-2.32)\end{array}$ & & $\begin{array}{c}-0.193^{* *} \\
(-2.34)\end{array}$ \\
\hline LNBM & & & $\begin{array}{c}0.209 * * * \\
(4.18)\end{array}$ & & $\begin{array}{c}0.209 * * * \\
(4.19)\end{array}$ \\
\hline MOM & & & $\begin{array}{l}0.303 \\
(1.39)\end{array}$ & & $\begin{array}{l}0.304 \\
(1.41)\end{array}$ \\
\hline IVOL & & & $\begin{array}{c}-0.123 * \\
(-1.78)\end{array}$ & & $\begin{array}{c}-0.123^{*} \\
(-1.77)\end{array}$ \\
\hline ILLIQ & & & $\begin{array}{c}0.036^{* * *} \\
(3.97)\end{array}$ & & $\begin{array}{c}0.036^{* * *} \\
(3.98)\end{array}$ \\
\hline LRET & & & $\begin{array}{c}-3.987 * * * \\
(-9.12)\end{array}$ & & $\begin{array}{c}-3.994 * * * \\
(-9.16)\end{array}$ \\
\hline LEV & & & $\begin{array}{c}-0.514^{* *} \\
(-2.03)\end{array}$ & & $\begin{array}{c}-0.512 * * \\
(-2.03)\end{array}$ \\
\hline IO & & & $\begin{array}{l}0.064 \\
(1.51)\end{array}$ & & $\begin{array}{l}0.063 \\
(1.50)\end{array}$ \\
\hline $\mathrm{COV}$ & & & $\begin{array}{l}0.038 \\
(1.32)\end{array}$ & & $\begin{array}{l}0.038 \\
(1.34)\end{array}$ \\
\hline LSUE & & & $\begin{array}{c}0.184^{* * *} \\
(5.00)\end{array}$ & & $\begin{array}{c}0.184^{* * *} \\
(4.93)\end{array}$ \\
\hline $\mathrm{N}$ & $1,524,222$ & $1,524,222$ & $1,445,747$ & $1,524,222$ & $1,445,747$ \\
\hline Adj. $R^{2}$ & 0.001 & 0.003 & 0.063 & 0.003 & \\
\hline
\end{tabular}




\section{Table 9 Earnings beta and Announcement Returns}

The table reports average estimates of monthly Fama-MacBeth cross-sectional regressions of announcement and non-announcement returns on earnings beta, VAR cash-flow beta and other control variables for announcing firms. In panel $\mathrm{A}$, the dependent variable is announcement return, defined as cumulative stock return over announcement window [-1,4]. In panel $B$, the dependent variable is nonannouncement return, defined as monthly return excluding announcement return. In model (1)-(4), the sample includes firms with earnings announcement in the return month. In model (5)-(8), the sample includes firms with either earnings or M\&A announcement in the return month. Earnings beta $\left(\beta^{E A}\right)$ is estimated based on daily returns over the 3-year rolling window. VAR cash-flow beta $\left(\beta^{C F(V A R)}\right)$ and VAR discount-rate beta $\left(\beta^{D R(V A R)}\right)$ are estimated based on monthly returns over 3-year rolling window using VAR cash-flow news and discount-rate news components. Control variables are the same as those in Table 7. $*, * *$, and $* * *$ denote significance at the $10 \%, 5 \%$, and $1 \%$ levels, respectively. The t-statistics are based on Newey-West standard errors with 12 lags.

Panel A: Announcement Returns

\begin{tabular}{|c|c|c|c|c|c|c|c|c|}
\hline \multirow[b]{3}{*}{$\beta^{E A}$} & \multicolumn{4}{|c|}{ Earnings Announcement } & \multicolumn{4}{|c|}{ Earnings or M\&A Announcement } \\
\hline & $(1)$ & $(2)$ & $(3)$ & $(4)$ & (5) & $(6)$ & $(7)$ & $(8)$ \\
\hline & $\begin{array}{c}0.072 * * \\
(2.47)\end{array}$ & $\begin{array}{c}0.062 * * \\
(2.21)\end{array}$ & & $\begin{array}{c}0.092^{* * *} \\
(3.28)\end{array}$ & $\begin{array}{c}0.074 * * * \\
(2.60)\end{array}$ & $\begin{array}{c}0.063^{* *} \\
(2.26)\end{array}$ & & $\begin{array}{c}0.093^{* * *} \\
(3.34)\end{array}$ \\
\hline$\beta^{C F(V A R)}$ & & & $\begin{array}{c}0.643 * * \\
(2.02)\end{array}$ & $\begin{array}{c}0.663 * * \\
(2.02)\end{array}$ & & & $\begin{array}{c}0.649 * * \\
(2.17)\end{array}$ & $\begin{array}{c}0.679 * * \\
(2.19)\end{array}$ \\
\hline$\beta^{D R(V A R)}$ & & & $\begin{array}{l}-0.114 \\
(-0.83)\end{array}$ & $\begin{array}{l}-0.112 \\
(-0.80)\end{array}$ & & & $\begin{array}{l}-0.099 \\
(-0.76)\end{array}$ & $\begin{array}{l}-0.094 \\
(-0.72)\end{array}$ \\
\hline$\beta^{C A P M}$ & & $\begin{array}{c}-0.306^{* * * *} \\
(-3.21)\end{array}$ & $\begin{array}{c}-0.375^{* * *} \\
(-3.64)\end{array}$ & $\begin{array}{c}-0.361 * * * \\
(-3.52)\end{array}$ & & $\begin{array}{c}-0.289 * * * \\
(-3.06)\end{array}$ & $\begin{array}{c}-0.352 * * * \\
(-3.41)\end{array}$ & $\begin{array}{c}-0.340 * * * \\
(-3.32)\end{array}$ \\
\hline LNSIZE & & $\begin{array}{c}-0.105^{* *} \\
(-2.15)\end{array}$ & $\begin{array}{l}-0.087 \\
(-1.54)\end{array}$ & $\begin{array}{c}-0.094 * \\
(-1.67)\end{array}$ & & $\begin{array}{c}-0.151^{* * * *} \\
(-3.31)\end{array}$ & $\begin{array}{c}-0.137 * * * \\
(-2.62)\end{array}$ & $\begin{array}{c}-0.142 * * * \\
(-2.71)\end{array}$ \\
\hline LNBM & & $\begin{array}{c}0.229 * * * \\
(5.24)\end{array}$ & $\begin{array}{c}0.204^{* * *} \\
(4.20)\end{array}$ & $\begin{array}{c}0.203^{* * *} \\
(4.17)\end{array}$ & & $\begin{array}{c}0.197 * * * \\
(4.75)\end{array}$ & $\begin{array}{c}0.181 * * * \\
(4.01)\end{array}$ & $\begin{array}{c}0.180 * * * \\
(3.98)\end{array}$ \\
\hline MOM & & $\begin{array}{l}0.087 \\
(1.12)\end{array}$ & $\begin{array}{l}0.030 \\
(0.27)\end{array}$ & $\begin{array}{l}0.031 \\
(0.28)\end{array}$ & & $\begin{array}{c}0.117^{*} \\
(1.66)\end{array}$ & $\begin{array}{l}0.060 \\
(0.62)\end{array}$ & $\begin{array}{l}0.061 \\
(0.63)\end{array}$ \\
\hline IVOL & & $\begin{array}{c}-0.472^{* * * *} \\
(-8.91)\end{array}$ & $\begin{array}{c}-0.474 * * * \\
(-9.20)\end{array}$ & $\begin{array}{c}-0.470 * * * \\
(-8.95)\end{array}$ & & $\begin{array}{c}-0.426 * * * \\
(-8.08)\end{array}$ & $\begin{array}{c}-0.435 * * * \\
(-8.18)\end{array}$ & $\begin{array}{c}-0.430 * * * \\
(-8.08)\end{array}$ \\
\hline ILLIQ & & $\begin{array}{c}0.098^{* * *} \\
(5.15)\end{array}$ & $\begin{array}{c}0.098^{* * *} \\
(5.30)\end{array}$ & $\begin{array}{c}0.098^{* * *} \\
(5.07)\end{array}$ & & $\begin{array}{c}0.096^{* * *} \\
(5.18)\end{array}$ & $\begin{array}{c}0.097 * * * \\
(5.35)\end{array}$ & $\begin{array}{c}0.097 * * * \\
(5.14)\end{array}$ \\
\hline LRET & & $\begin{array}{c}-0.849 * * * \\
(-2.91)\end{array}$ & $\begin{array}{c}-1.072 * * * \\
(-3.11)\end{array}$ & $\begin{array}{c}-1.080 * * * \\
(-3.19)\end{array}$ & & $\begin{array}{c}-0.949 * * * \\
(-3.33)\end{array}$ & $\begin{array}{c}-1.103 * * * \\
(-3.32)\end{array}$ & $\begin{array}{c}-1.123 * * * \\
(-3.45)\end{array}$ \\
\hline LEV & & $\begin{array}{l}-0.064 \\
(-0.51)\end{array}$ & $\begin{array}{l}-0.131 \\
(-1.04)\end{array}$ & $\begin{array}{l}-0.127 \\
(-1.00)\end{array}$ & & $\begin{array}{l}-0.072 \\
(-0.58)\end{array}$ & $\begin{array}{l}-0.136 \\
(-1.11)\end{array}$ & $\begin{array}{l}-0.133 \\
(-1.08)\end{array}$ \\
\hline IO & & $\begin{array}{c}0.184^{* * *} \\
(5.50)\end{array}$ & $\begin{array}{c}0.166^{* * *} \\
(4.46)\end{array}$ & $\begin{array}{c}0.167 * * * \\
(4.49)\end{array}$ & & $\begin{array}{c}0.194^{* * *} \\
(5.75)\end{array}$ & $\begin{array}{c}0.183^{* * *} \\
(4.85)\end{array}$ & $\begin{array}{c}0.183^{* * *} \\
(4.87)\end{array}$ \\
\hline $\mathrm{COV}$ & & $\begin{array}{c}0.106^{* * *} \\
(3.98)\end{array}$ & $\begin{array}{c}0.100^{* * *} \\
(3.59)\end{array}$ & $\begin{array}{c}0.100 * * * \\
(3.56)\end{array}$ & & $\begin{array}{c}0.102^{* * *} \\
(4.19)\end{array}$ & $\begin{array}{c}0.095^{* * *} \\
(3.63)\end{array}$ & $\begin{array}{c}0.095^{* * *} \\
(3.57)\end{array}$ \\
\hline LSUE & & $\begin{array}{l}-0.019 \\
(-0.28)\end{array}$ & $\begin{array}{l}-0.011 \\
(-0.14)\end{array}$ & $\begin{array}{l}-0.016 \\
(-0.21)\end{array}$ & & $\begin{array}{l}-0.005 \\
(-0.07)\end{array}$ & $\begin{array}{l}0.006 \\
(0.08)\end{array}$ & $\begin{array}{l}0.002 \\
(0.02)\end{array}$ \\
\hline $\mathrm{N}$ & 472396 & 452,620 & 374,647 & 373,950 & 482,901 & 462,733 & 383,263 & 382,557 \\
\hline Adj. $R^{2}$ & 0.003 & 0.027 & 0.028 & 0.029 & 0.003 & 0.027 & 0.028 & 0.029 \\
\hline
\end{tabular}


Panel B: Non-announcement Returns

\begin{tabular}{|c|c|c|c|c|c|c|c|c|}
\hline \multirow[b]{3}{*}{$\beta^{E A}$} & \multicolumn{4}{|c|}{ Earnings Announcement } & \multicolumn{4}{|c|}{ Earnings or M\&A Announcement } \\
\hline & $(1)$ & $(2)$ & (3) & (4) & (5) & $(6)$ & $(7)$ & (8) \\
\hline & $\begin{array}{l}0.009 \\
(0.32)\end{array}$ & $\begin{array}{l}-0.013 \\
(-0.50)\end{array}$ & & $\begin{array}{l}-0.023 \\
(-0.78)\end{array}$ & $\begin{array}{l}0.009 \\
(0.35)\end{array}$ & $\begin{array}{l}-0.007 \\
(-0.30)\end{array}$ & & $\begin{array}{l}-0.016 \\
(-0.57)\end{array}$ \\
\hline$\beta^{C F(V A R)}$ & & & $\begin{array}{l}0.333 \\
(0.88)\end{array}$ & $\begin{array}{l}0.293 \\
(0.78)\end{array}$ & & & $\begin{array}{l}0.271 \\
(0.75)\end{array}$ & $\begin{array}{l}0.231 \\
(0.64)\end{array}$ \\
\hline$\beta^{D S(V A R)}$ & & & $\begin{array}{c}0.172 \\
(1.47)\end{array}$ & $\begin{array}{l}0.157 \\
(1.29)\end{array}$ & & & $\begin{array}{l}0.119 \\
(1.01)\end{array}$ & $\begin{array}{l}0.104 \\
(0.85)\end{array}$ \\
\hline$\beta^{C A P M}$ & & $\begin{array}{l}0.298 \\
(1.51)\end{array}$ & $\begin{array}{l}0.411^{*} \\
(1.96)\end{array}$ & $\begin{array}{c}0.412^{* *} \\
(1.98)\end{array}$ & & $\begin{array}{l}0.279 \\
(1.45)\end{array}$ & $\begin{array}{l}0.398^{*} \\
(1.95)\end{array}$ & $\begin{array}{c}0.400^{* *} \\
(1.98)\end{array}$ \\
\hline LNSIZE & & $\begin{array}{l}-0.118 \\
(-1.53)\end{array}$ & $\begin{array}{l}-0.087 \\
(-1.03)\end{array}$ & $\begin{array}{l}-0.082 \\
(-0.98)\end{array}$ & & $\begin{array}{c}-0.139 * \\
(-1.85)\end{array}$ & $\begin{array}{l}-0.117 \\
(-1.41)\end{array}$ & $\begin{array}{l}-0.113 \\
(-1.37)\end{array}$ \\
\hline LNBM & & $\begin{array}{l}0.075 \\
(1.29)\end{array}$ & $\begin{array}{c}0.125^{* *} \\
(2.11)\end{array}$ & $\begin{array}{c}0.122 * * \\
(2.09)\end{array}$ & & $\begin{array}{l}0.070 \\
(1.17)\end{array}$ & $\begin{array}{c}0.120^{* *} \\
(2.01)\end{array}$ & $\begin{array}{c}0.116^{* *} \\
(1.97)\end{array}$ \\
\hline MOM & & $\begin{array}{c}0.421^{* *} \\
(2.28)\end{array}$ & $\begin{array}{c}0.491 * * \\
(2.43)\end{array}$ & $\begin{array}{c}0.491^{* *} \\
(2.39)\end{array}$ & & $\begin{array}{c}0.468^{* * *} \\
(2.69)\end{array}$ & $\begin{array}{c}0.533^{* * *} \\
(2.81)\end{array}$ & $\begin{array}{c}0.534^{* * *} \\
(2.78)\end{array}$ \\
\hline IVOL & & $\begin{array}{l}0.167 \\
(1.58)\end{array}$ & $\begin{array}{l}0.152 \\
(1.31)\end{array}$ & $\begin{array}{l}0.157 \\
(1.32)\end{array}$ & & $\begin{array}{l}0.193^{*} \\
(1.71)\end{array}$ & $\begin{array}{l}0.176 \\
(1.42)\end{array}$ & $\begin{array}{l}0.180 \\
(1.42)\end{array}$ \\
\hline ILLIQ & & $\begin{array}{l}-0.006 \\
(-0.47)\end{array}$ & $\begin{array}{l}0.007 \\
(0.63)\end{array}$ & $\begin{array}{l}0.009 \\
(0.77)\end{array}$ & & $\begin{array}{l}-0.007 \\
(-0.57)\end{array}$ & $\begin{array}{l}0.005 \\
(0.43)\end{array}$ & $\begin{array}{l}0.007 \\
(0.58)\end{array}$ \\
\hline LRET & & $\begin{array}{c}-4.176^{* * *} \\
(-9.46)\end{array}$ & $\begin{array}{c}-4.996 * * * \\
(-11.62)\end{array}$ & $\begin{array}{c}-4.975 * * * \\
(-11.52)\end{array}$ & & $\begin{array}{c}-4.149 * * * \\
(-9.55)\end{array}$ & $\begin{array}{c}-4.968 * * * \\
(-11.72)\end{array}$ & $\begin{array}{c}-4.940 * * * \\
(-11.63)\end{array}$ \\
\hline LEV & & $\begin{array}{l}-0.219 \\
(-1.07)\end{array}$ & $\begin{array}{l}-0.263 \\
(-1.13)\end{array}$ & $\begin{array}{l}-0.264 \\
(-1.14)\end{array}$ & & $\begin{array}{l}-0.214 \\
(-1.11)\end{array}$ & $\begin{array}{l}-0.269 \\
(-1.22)\end{array}$ & $\begin{array}{l}-0.268 \\
(-1.23)\end{array}$ \\
\hline IO & & $\begin{array}{l}0.010 \\
(0.29)\end{array}$ & $\begin{array}{l}-0.013 \\
(-0.34)\end{array}$ & $\begin{array}{l}-0.012 \\
(-0.31)\end{array}$ & & $\begin{array}{l}0.011 \\
(0.32)\end{array}$ & $\begin{array}{l}-0.011 \\
(-0.31)\end{array}$ & $\begin{array}{l}-0.011 \\
(-0.30)\end{array}$ \\
\hline $\mathrm{COV}$ & & $\begin{array}{l}-0.023 \\
(-0.62)\end{array}$ & $\begin{array}{l}-0.018 \\
(-0.46)\end{array}$ & $\begin{array}{l}-0.020 \\
(-0.53)\end{array}$ & & $\begin{array}{l}-0.032 \\
(-0.99)\end{array}$ & $\begin{array}{l}-0.024 \\
(-0.77)\end{array}$ & $\begin{array}{l}-0.026 \\
(-0.84)\end{array}$ \\
\hline LSUE & & $\begin{array}{c}0.180^{* *} \\
(2.47)\end{array}$ & $\begin{array}{c}0.154^{* *} \\
(2.01)\end{array}$ & $\begin{array}{c}0.168 * * \\
(2.16)\end{array}$ & & $\begin{array}{c}0.161^{* *} \\
(2.12)\end{array}$ & $\begin{array}{l}0.135^{*} \\
(1.67)\end{array}$ & $\begin{array}{l}0.148^{*} \\
(1.81)\end{array}$ \\
\hline $\mathrm{N}$ & 472,396 & 452,620 & 374,647 & 373,950 & 482,901 & 462,733 & 383,263 & 382,557 \\
\hline Adj. $\mathrm{R}^{2}$ & 0.002 & 0.059 & 0.059 & 0.061 & 0.002 & 0.059 & 0.059 & 0.06 \\
\hline
\end{tabular}




\section{Table 10 Effect of Earnings Uncertainty}

The table reports average estimates of monthly Fama-MacBeth cross-sectional regressions of announcement returns on earnings beta interacting with cash-flow uncertainty dummies and other control variables. The dependent variable is announcement return, defined as cumulative stock return over announcement window [-1,4]. In model (1) and (2), the sample includes firms with earnings announcement in the return month. In model (3) and (4), the sample includes firms with either earnings or M\&A announcement in the return month. In panel A, high cash-flow uncertainty dummy is defined as $d^{H E U}=1$ if the firm has standard deviation of earnings surprise higher than the cross-sectional median and $d^{H E U}$ is zero otherwise. Standardized earnings surprise is estimated from a seasonal random walk model and the standard deviation is calculated each quarter over the previous twelve quarters. Low cash-flow uncertainty dummy is defined as $d^{L E U}=1-d^{H E U}$. In panel $\mathrm{B}$, low analyst coverage dummy is defined as $d^{L C O V}=1$ if the firm has residual analyst coverage lower than the cross-sectional median and $d^{L C O V}$ is zero otherwise. High analyst coverage dummy is defined as $d^{H C O V}=1-d^{L C O V}$. Earnings beta $\left(\beta^{E A}\right)$ is estimated based on daily returns over the 3-year rolling window. Control variables are the same as those in Table $7 . *{ }^{*}$, , and *** denote significance at the $10 \%, 5 \%$, and $1 \%$ levels, respectively. The t-statistics are based on Newey-West standard errors with 12 lags.

\begin{tabular}{|c|c|c|c|c|}
\hline \multirow[b]{3}{*}{$\beta^{E A *} d^{H E U}$} & \multicolumn{2}{|c|}{ Earnings Announcement } & \multicolumn{2}{|c|}{ Earnings or M\&A Announcemen } \\
\hline & $(1)$ & $(2)$ & (3) & $(4)$ \\
\hline & $\begin{array}{c}0.090^{* * *} \\
(2.66)\end{array}$ & $\begin{array}{c}0.072 * * \\
(2.06)\end{array}$ & $\begin{array}{c}0.092 * * * \\
(2.82)\end{array}$ & $\begin{array}{c}0.072 * * \\
(2.15)\end{array}$ \\
\hline$\beta^{E A *} d^{L E U}$ & $\begin{array}{r}0.038 \\
(0.89)\end{array}$ & $\begin{array}{l}0.050 \\
(1.23)\end{array}$ & $\begin{array}{r}0.043 \\
(0.99)\end{array}$ & $\begin{array}{l}0.056 \\
(1.35)\end{array}$ \\
\hline$d^{H C F U}$ & $\begin{array}{l}-0.057 \\
(-0.90)\end{array}$ & $\begin{array}{c}-0.091 * \\
(-1.81)\end{array}$ & $\begin{array}{l}-0.017 \\
(-0.28)\end{array}$ & $\begin{array}{l}-0.070 \\
(-1.42)\end{array}$ \\
\hline$\beta^{C A P M}$ & & $\begin{array}{c}-0.279 * * * \\
(-2.86)\end{array}$ & & $\begin{array}{c}-0.264^{* * *} \\
(-2.71)\end{array}$ \\
\hline LNSIZE & & $\begin{array}{c}-0.133^{* * * *} \\
(-2.59)\end{array}$ & & $\begin{array}{c}-0.173 * * * \\
(-3.54)\end{array}$ \\
\hline LNBM & & $\begin{array}{c}0.227 * * * \\
(5.06)\end{array}$ & & $\begin{array}{c}0.192 * * * \\
(4.54)\end{array}$ \\
\hline MOM & & $\begin{array}{l}0.101 \\
(1.28)\end{array}$ & & $\begin{array}{l}0.128^{*} \\
(1.83)\end{array}$ \\
\hline IVOL & & $\begin{array}{c}-0.460 * * * \\
(-8.92)\end{array}$ & & $\begin{array}{c}-0.417 * * * \\
(-8.01)\end{array}$ \\
\hline ILLIQ & & $\begin{array}{c}0.099 * * * \\
(5.24)\end{array}$ & & $\begin{array}{c}0.097 * * * \\
(5.29)\end{array}$ \\
\hline LRET & & $\begin{array}{c}-0.906 * * * \\
(-3.25)\end{array}$ & & $\begin{array}{c}-1.010 * * * \\
(-3.68)\end{array}$ \\
\hline LEV & & $\begin{array}{l}-0.036 \\
(-0.28)\end{array}$ & & $\begin{array}{l}-0.043 \\
(-0.33)\end{array}$ \\
\hline IO & & $\begin{array}{c}0.180^{* * *} \\
(5.34)\end{array}$ & & $\begin{array}{c}0.192^{* * *} \\
(5.61)\end{array}$ \\
\hline $\mathrm{COV}$ & & $\begin{array}{c}0.110^{* * *} \\
(4.29)\end{array}$ & & $\begin{array}{c}0.104^{* * *} \\
(4.32)\end{array}$ \\
\hline LSUE & & $\begin{array}{l}-0.007 \\
(-0.10)\end{array}$ & & $\begin{array}{l}0.003 \\
(0.04)\end{array}$ \\
\hline $\mathrm{N}$ & 466,407 & 447,112 & 476,655 & 456,983 \\
\hline Adj. $\mathrm{R}^{2}$ & 0.003 & 0.028 & 0.003 & 0.027 \\
\hline
\end{tabular}




\begin{tabular}{|c|c|c|c|c|}
\hline \multirow[b]{3}{*}{$\beta^{E A *} d^{L C O V}$} & \multicolumn{2}{|c|}{ Earnings Announcement } & \multicolumn{2}{|c|}{ Earnings or M\&A Announcement } \\
\hline & $(1)$ & $(2)$ & (3) & $(4)$ \\
\hline & $\begin{array}{c}0.120 * * * \\
(3.25)\end{array}$ & $\begin{array}{c}0.119 * * * \\
(3.07)\end{array}$ & $\begin{array}{c}0.126 * * * \\
(3.45)\end{array}$ & $\begin{array}{c}0.118^{* * *} \\
(3.13)\end{array}$ \\
\hline$\beta^{E A *} d^{H C O V}$ & $\begin{array}{l}0.043 \\
(1.17)\end{array}$ & $\begin{array}{l}0.019 \\
(0.51)\end{array}$ & $\begin{array}{l}0.041 \\
(1.14)\end{array}$ & $\begin{array}{c}0.022 \\
(0.61)\end{array}$ \\
\hline$d^{\mathrm{HCOV}}$ & $\begin{array}{c}0.200^{* * *} \\
(3.53)\end{array}$ & $\begin{array}{l}0.051 \\
(0.83)\end{array}$ & $\begin{array}{c}0.224^{* * *} \\
(4.15)\end{array}$ & $\begin{array}{l}0.087 \\
(1.43)\end{array}$ \\
\hline$\beta^{C A P M}$ & & $\begin{array}{c}-0.322 * * * \\
(-3.25)\end{array}$ & & $\begin{array}{c}-0.305^{* * *} \\
(-3.15)\end{array}$ \\
\hline LNSIZE & & $\begin{array}{c}-0.091^{*} \\
(-1.93)\end{array}$ & & $\begin{array}{c}-0.124 * * * \\
(-2.78)\end{array}$ \\
\hline LNBM & & $\begin{array}{c}0.236^{* * *} \\
(5.39)\end{array}$ & & $\begin{array}{c}0.206^{* * *} \\
(4.96)\end{array}$ \\
\hline MOM & & $\begin{array}{l}0.079 \\
(1.01)\end{array}$ & & $\begin{array}{l}0.110 \\
(1.54)\end{array}$ \\
\hline IVOL & & $\begin{array}{c}-0.355^{* * *} \\
(-8.68)\end{array}$ & & $\begin{array}{c}-0.323^{* * *} \\
(-7.78)\end{array}$ \\
\hline ILLIQ & & $\begin{array}{c}0.098^{* * *} \\
(5.17)\end{array}$ & & $\begin{array}{c}0.096 * * * \\
(5.18)\end{array}$ \\
\hline LRET & & $\begin{array}{c}-0.879 * * * \\
(-3.03)\end{array}$ & & $\begin{array}{c}-0.977 * * * \\
(-3.47)\end{array}$ \\
\hline LEV & & $\begin{array}{l}-0.064 \\
(-0.51)\end{array}$ & & $\begin{array}{l}-0.078 \\
(-0.63)\end{array}$ \\
\hline IO & & $\begin{array}{c}0.179 * * * \\
(5.37)\end{array}$ & & $\begin{array}{c}0.187^{* * *} \\
(5.52)\end{array}$ \\
\hline $\mathrm{COV}$ & & $\begin{array}{c}0.096^{* *} \\
(2.59)\end{array}$ & & $\begin{array}{c}0.076^{* *} \\
(2.39)\end{array}$ \\
\hline LSUE & & $\begin{array}{l}-0.031 \\
(-0.57)\end{array}$ & & $\begin{array}{l}-0.020 \\
(-0.41)\end{array}$ \\
\hline $\mathrm{N}$ & 472,276 & 452,620 & 482,781 & 462,733 \\
\hline Adj. $\mathrm{R}^{2}$ & 0.003 & 0.028 & 0.003 & 0.028 \\
\hline
\end{tabular}




\section{Table 11 Effect of Investor Attention}

The table reports average estimates of monthly Fama-MacBeth cross-sectional regressions of announcement returns on earnings beta interacting with investor attention dummies and other control variables. The dependent variable is announcement return, defined as cumulative stock return over announcement window $[-1,4]$. In model (1) and (2), the sample includes firms with earnings announcement in the return month. In model (3) and (4), the sample includes firms with either earnings or M\&A announcement in the return month. In panel A, high investor attention dummy is defined as $d^{H E T O}=1$ if the firm has log excess turnover higher than the cross-sectional median and $d^{H E T O}$ is zero otherwise. Low investor attention dummy is defined as $d^{L E T O}=1-d^{H E T O}$. In panel $\mathrm{B}$, high investor attention dummy is defined as $d^{H E T V}=1$ if the firm has log excess trading volume higher than the cross-sectional median and $d^{H E T V}$ is zero otherwise. Low investor attention dummy is defined as $d^{L E T V}=1-d^{H E T V}$. Earnings beta $\left(\beta^{E A}\right)$ is estimated based on daily returns over the 3-year rolling window. Control variables are the same as those in Table 7. *, **, and $* * *$ denote significance at the $10 \%, 5 \%$, and $1 \%$ levels, respectively. The t-statistics are based on Newey-West standard errors with 12 lags.

Panel A: Excess Turnover

\begin{tabular}{|c|c|c|c|c|}
\hline \multirow[b]{3}{*}{$\beta^{E A *} d^{H E T O}$} & \multicolumn{2}{|c|}{ Earnings Announcement } & \multicolumn{2}{|c|}{ Earnings or M\&A Announcement } \\
\hline & $(1)$ & $(2)$ & $(3)$ & $(4)$ \\
\hline & $\begin{array}{c}0.102^{* *} \\
(2.19)\end{array}$ & $\begin{array}{l}0.086^{*} \\
(1.84)\end{array}$ & $\begin{array}{c}0.105^{* *} \\
(2.23)\end{array}$ & $\begin{array}{l}0.087^{*} \\
(1.87)\end{array}$ \\
\hline$\beta^{E A *} d^{L E T O}$ & $\begin{array}{l}0.027 \\
(1.00)\end{array}$ & $\begin{array}{l}0.026 \\
(0.91)\end{array}$ & $\begin{array}{c}0.032 \\
(1.28)\end{array}$ & $\begin{array}{l}0.031 \\
(1.15)\end{array}$ \\
\hline$d^{\text {HETO }}$ & $\begin{array}{c}1.454^{* * *} \\
(10.19)\end{array}$ & $\begin{array}{c}1.337 * * * \\
(9.28)\end{array}$ & $\begin{array}{c}1.391 * * * \\
(9.88)\end{array}$ & $\begin{array}{c}1.274 * * * \\
(8.97)\end{array}$ \\
\hline$\beta^{C A P M}$ & & $\begin{array}{c}-0.430 * * * \\
(-4.76)\end{array}$ & & $\begin{array}{c}-0.400 * * * \\
(-4.45)\end{array}$ \\
\hline LNSIZE & & $\begin{array}{l}-0.027 \\
(-0.58)\end{array}$ & & $\begin{array}{c}-0.076^{*} \\
(-1.76)\end{array}$ \\
\hline LNBM & & $\begin{array}{c}0.225^{* * *} \\
(5.21)\end{array}$ & & $\begin{array}{c}0.194 * * * \\
(4.68)\end{array}$ \\
\hline MOM & & $\begin{array}{l}0.067 \\
(0.87)\end{array}$ & & $\begin{array}{l}0.100 \\
(1.44)\end{array}$ \\
\hline IVOL & & $\begin{array}{c}-0.365^{* * * *} \\
(-6.94)\end{array}$ & & $\begin{array}{c}-0.329 * * * \\
(-6.19)\end{array}$ \\
\hline ILLIQ & & $\begin{array}{c}0.092^{* * *} \\
(5.01)\end{array}$ & & $\begin{array}{c}0.089 * * * \\
(5.04)\end{array}$ \\
\hline LRET & & $\begin{array}{c}-0.893 * * * \\
(-3.10)\end{array}$ & & $\begin{array}{c}-1.009 * * * \\
(-3.60)\end{array}$ \\
\hline LEV & & $\begin{array}{l}0.034 \\
(0.28)\end{array}$ & & $\begin{array}{l}0.014 \\
(0.11)\end{array}$ \\
\hline IO & & $\begin{array}{c}0.154^{* * *} \\
(4.79)\end{array}$ & & $\begin{array}{c}0.164 * * * \\
(5.17)\end{array}$ \\
\hline $\mathrm{COV}$ & & $\begin{array}{c}0.091^{* * *} \\
(3.37)\end{array}$ & & $\begin{array}{c}0.092^{* * *} \\
(3.69)\end{array}$ \\
\hline LSUE & & $\begin{array}{l}-0.033 \\
(-0.50)\end{array}$ & & $\begin{array}{l}-0.021 \\
(-0.34)\end{array}$ \\
\hline $\mathrm{N}$ & 471,141 & 452,163 & 481,621 & 462,276 \\
\hline Adj. $R^{2}$ & 0.012 & 0.037 & 0.012 & 0.037 \\
\hline
\end{tabular}


Panel B: Excess Trading Volume

\begin{tabular}{|c|c|c|c|c|}
\hline \multirow[b]{3}{*}{$\beta^{E A *} d^{H E T V}$} & \multicolumn{2}{|c|}{ Earnings Announcement } & \multicolumn{2}{|c|}{ Earnings or M\&A Announcement } \\
\hline & $(1)$ & $(2)$ & (3) & (4) \\
\hline & $\begin{array}{l}0.090 * \\
(1.80)\end{array}$ & $\begin{array}{l}0.077 \\
(1.58)\end{array}$ & $\begin{array}{c}0.100^{* *} \\
(2.11)\end{array}$ & $\begin{array}{l}\text { 0.085* } \\
(1.85)\end{array}$ \\
\hline$\beta^{E A *} d^{L E T V}$ & $\begin{array}{l}0.039 \\
(1.33)\end{array}$ & $\begin{array}{l}0.041 \\
(1.40)\end{array}$ & $\begin{array}{l}0.035 \\
(1.40)\end{array}$ & $\begin{array}{l}0.040 \\
(1.48)\end{array}$ \\
\hline$d^{H E T V}$ & $\begin{array}{c}2.374^{* * * *} \\
(16.67)\end{array}$ & $\begin{array}{c}2.264^{* * *} \\
(16.35)\end{array}$ & $\begin{array}{c}2.294^{* * *} \\
(16.51)\end{array}$ & $\begin{array}{c}2.184 * * * \\
(16.33)\end{array}$ \\
\hline$\beta^{C A P M}$ & & $\begin{array}{c}-0.493 * * * \\
(-5.87)\end{array}$ & & $\begin{array}{c}-0.460^{* * *} \\
(-5.50)\end{array}$ \\
\hline LNSIZE & & $\begin{array}{l}-0.005 \\
(-0.10)\end{array}$ & & $\begin{array}{l}-0.058 \\
(-1.38)\end{array}$ \\
\hline LNBM & & $\begin{array}{c}0.237^{* * * *} \\
(5.66)\end{array}$ & & $\begin{array}{c}0.203^{* * *} \\
(5.05)\end{array}$ \\
\hline MOM & & $\begin{array}{l}0.023 \\
(0.32)\end{array}$ & & $\begin{array}{l}0.053 \\
(0.81)\end{array}$ \\
\hline IVOL & & $\begin{array}{c}-0.268 * * * \\
(-5.24)\end{array}$ & & $\begin{array}{c}-0.237 * * * \\
(-4.61)\end{array}$ \\
\hline ILLIQ & & $\begin{array}{c}0.084^{* * *} \\
(4.67)\end{array}$ & & $\begin{array}{c}0.082^{* * *} \\
(4.73)\end{array}$ \\
\hline LRET & & $\begin{array}{c}-1.561 * * * \\
(-5.26)\end{array}$ & & $\begin{array}{c}-1.623 * * * \\
(-5.65)\end{array}$ \\
\hline LEV & & $\begin{array}{l}0.091 \\
(0.75)\end{array}$ & & $\begin{array}{l}0.072 \\
(0.59)\end{array}$ \\
\hline IO & & $\begin{array}{c}0.125^{* * *} \\
(4.16)\end{array}$ & & $\begin{array}{c}0.137 * * * \\
(4.58)\end{array}$ \\
\hline $\mathrm{COV}$ & & $\begin{array}{c}0.065^{* *} \\
(2.41)\end{array}$ & & $\begin{array}{c}0.073^{* * * *} \\
(2.94)\end{array}$ \\
\hline LSUE & & $\begin{array}{l}-0.039 \\
(-0.60)\end{array}$ & & $\begin{array}{l}-0.026 \\
(-0.42)\end{array}$ \\
\hline $\mathrm{N}$ & 471,141 & 452,163 & 481,621 & 462,276 \\
\hline Adj. $R^{2}$ & 0.019 & 0.044 & 0.018 & 0.043 \\
\hline
\end{tabular}




\section{Table 12 Effect of Announcement Timing: Early Announcers in an Earnings Cycle}

The table reports average estimates of monthly Fama-MacBeth cross-sectional regressions of announcement returns on earnings beta interacting with timing dummies and other control variables. In models (1) and (2), dummy variable for early announcers is defined as $d^{\text {Early }}=1$ if the firm has earnings announcement falling in the earliest quintile in a given fiscal quarter and $d^{\text {Early }}$ is zero otherwise. In models (3) and (4), $d^{\text {Early }=1}$ if the firm has earnings announcement falling in the earliest tercile in a given fiscal quarter. Dummy variable for other firms is defined as $d^{\text {Others }}=1-d^{\text {Early }}$. The dependent variable is announcement return, defined as cumulative stock return over announcement window [-1,4]. Earnings beta $\left(\beta^{E A}\right)$ is estimated based on daily returns over the 3-year rolling window. Control variables are the same as those in Table 7. *, **, and $* * *$ denote significance at the $10 \%, 5 \%$, and $1 \%$ levels, respectively. The tstatistics of regression estimates are based on Newey-West standard errors with 12 lags.

\begin{tabular}{|c|c|c|c|c|}
\hline \multirow[b]{3}{*}{$\beta^{E A *} d^{\text {Early }}$} & \multicolumn{2}{|c|}{ Earliest Quintile } & \multicolumn{2}{|c|}{ Earliest Tercile } \\
\hline & (1) & $(2)$ & (3) & (4) \\
\hline & $\begin{array}{c}0.167 * * * \\
(3.31)\end{array}$ & $\begin{array}{c}0.155^{* * *} \\
(3.18)\end{array}$ & $\begin{array}{c}0.120 * * * \\
(3.00)\end{array}$ & $\begin{array}{c}0.098 * * \\
(2.41)\end{array}$ \\
\hline$\beta^{E A *} d^{\text {Others }}$ & $\begin{array}{l}0.032 \\
(0.88)\end{array}$ & $\begin{array}{l}0.021 \\
(0.55)\end{array}$ & $\begin{array}{l}0.038 \\
(1.05)\end{array}$ & $\begin{array}{l}0.023 \\
(0.62)\end{array}$ \\
\hline$\beta^{C A P M}$ & & $\begin{array}{c}-0.303 * * * \\
(-3.21)\end{array}$ & & $\begin{array}{c}-0.303 * * * \\
(-3.18)\end{array}$ \\
\hline LNSIZE & & $\begin{array}{c}-0.099 * * \\
(-2.35)\end{array}$ & & $\begin{array}{c}-0.097 * * \\
(-2.32)\end{array}$ \\
\hline LNBM & & $\begin{array}{c}0.230^{* * *} \\
(5.26)\end{array}$ & & $\begin{array}{c}0.232 * * * \\
(5.27)\end{array}$ \\
\hline MOM & & $\begin{array}{l}0.094 \\
(1.22)\end{array}$ & & $\begin{array}{l}0.094 \\
(1.21)\end{array}$ \\
\hline IVOL & & $\begin{array}{c}-0.313^{* * *} \\
(-7.41)\end{array}$ & & $\begin{array}{c}-0.314 * * * \\
(-7.47)\end{array}$ \\
\hline ILLIQ & & $\begin{array}{c}0.098^{* * *} \\
(5.16)\end{array}$ & & $\begin{array}{c}0.098^{* * *} \\
(5.12)\end{array}$ \\
\hline LRET & & $\begin{array}{c}-0.856 * * * \\
(-2.96)\end{array}$ & & $\begin{array}{c}-0.875 * * * \\
(-3.01)\end{array}$ \\
\hline LEV & & $\begin{array}{l}-0.064 \\
(-0.50)\end{array}$ & & $\begin{array}{l}-0.071 \\
(-0.55)\end{array}$ \\
\hline IO & & $\begin{array}{c}0.183^{* * *} \\
(5.58)\end{array}$ & & $\begin{array}{c}0.182^{* * *} \\
(5.56)\end{array}$ \\
\hline $\mathrm{COV}$ & & $\begin{array}{c}0.101^{* * *} \\
(3.87)\end{array}$ & & $\begin{array}{c}0.101^{* * *} \\
(3.84)\end{array}$ \\
\hline LSUE & & $\begin{array}{l}0.042 \\
(0.77)\end{array}$ & & $\begin{array}{l}0.037 \\
(0.68)\end{array}$ \\
\hline $\mathrm{N}$ & 472,396 & 452,620 & 472,396 & 452,620 \\
\hline Adj. $R^{2}$ & 0.002 & 0.028 & 0.002 & 0.028 \\
\hline
\end{tabular}




\section{Table 13 Effect of Announcement Timing: On-time Announcements}

The table reports average estimates of monthly Fama-MacBeth cross-sectional regressions of announcement returns on earnings beta interacting with timing dummies and other control variables. Following So and Wang (2014), expected earnings announcement dates for each firm/fiscal quarter are based on the median number of trading days between the calendar quarter end and firm's earnings announcement date for the same fiscal quarter over the past 10 years. In models (1) and (2), dummy variable for firms with on-time announcements is defined as $d^{\text {Timely }}=1$ if the actual announcement date is within one trading day of expected announcement date and $d^{\text {Timely }}$ is zero otherwise. In models (3) and (4), $d^{\text {Timely }}=1$ if the actual announcement date is within two trading days of expected announcement date. Dummy variable for other firms is defined as $d^{\text {others }}=1-d^{\text {Timely }}$. The dependent variable is announcement return, defined as cumulative stock return over announcement window [-1,4]. Earnings beta $\left(\beta^{E A}\right)$ is estimated based on daily returns over the 3-year rolling window. Control variables are the same as those in Table 7. *, **, and $* * *$ denote significance at the $10 \%, 5 \%$, and $1 \%$ levels, respectively. The t-statistics of regression estimates are based on Newey-West standard errors with 12 lags.

\begin{tabular}{|c|c|c|c|c|}
\hline \multirow[b]{3}{*}{$\beta^{E A} * d^{\text {Timely }}$} & \multicolumn{2}{|c|}{ Within One-Trading Day } & \multicolumn{2}{|c|}{ Within Two-Trading Days } \\
\hline & $(1)$ & $(2)$ & $(3)$ & (4) \\
\hline & $\begin{array}{c}0.109 * * \\
(2.14)\end{array}$ & $\begin{array}{c}0.101^{* *} \\
(2.04)\end{array}$ & $\begin{array}{c}0.108 * * * \\
(2.62)\end{array}$ & $\begin{array}{c}0.102 * * \\
(2.56)\end{array}$ \\
\hline$\beta^{E A *} d^{\text {Others }}$ & $\begin{array}{l}0.057 \\
(1.59)\end{array}$ & $\begin{array}{l}0.045 \\
(1.28)\end{array}$ & $\begin{array}{l}0.042 \\
(1.02)\end{array}$ & $\begin{array}{l}0.030 \\
(0.78)\end{array}$ \\
\hline$\beta^{C A P M}$ & & $\begin{array}{c}-0.304 * * * \\
(-3.21)\end{array}$ & & $\begin{array}{c}-0.308^{* * * *} \\
(-3.25)\end{array}$ \\
\hline LNSIZE & & $\begin{array}{c}-0.107 * * \\
(-2.20)\end{array}$ & & $\begin{array}{c}-0.104^{* *} \\
(-2.15)\end{array}$ \\
\hline LNBM & & $\begin{array}{c}0.228^{* * *} \\
(5.13)\end{array}$ & & $\begin{array}{c}0.227 * * * \\
(5.20)\end{array}$ \\
\hline MOM & & $\begin{array}{l}0.095 \\
(1.23)\end{array}$ & & $\begin{array}{l}0.093 \\
(1.19)\end{array}$ \\
\hline IVOL & & $\begin{array}{c}-0.478 * * * \\
(-8.99)\end{array}$ & & $\begin{array}{c}-0.473 * * * \\
(-8.76)\end{array}$ \\
\hline ILLIQ & & $\begin{array}{c}0.099 * * * \\
(5.13)\end{array}$ & & $\begin{array}{c}0.098 * * * \\
(5.16)\end{array}$ \\
\hline LRET & & $\begin{array}{c}-0.837 * * * \\
(-2.88)\end{array}$ & & $\begin{array}{c}-0.827 * * * \\
(-2.83)\end{array}$ \\
\hline LEV & & $\begin{array}{l}-0.062 \\
(-0.49)\end{array}$ & & $\begin{array}{l}-0.061 \\
(-0.49)\end{array}$ \\
\hline IO & & $\begin{array}{c}0.183^{* * *} \\
(5.48)\end{array}$ & & $\begin{array}{c}0.184^{* * *} \\
(5.49)\end{array}$ \\
\hline $\mathrm{COV}$ & & $\begin{array}{c}0.106^{* * *} \\
(3.95)\end{array}$ & & $\begin{array}{c}0.105^{* * *} \\
(3.89)\end{array}$ \\
\hline LSUE & & $\begin{array}{l}-0.016 \\
(-0.24)\end{array}$ & & $\begin{array}{l}-0.020 \\
(-0.29)\end{array}$ \\
\hline $\mathrm{N}$ & 472,396 & 452,620 & 472,396 & 452,620 \\
\hline Adj. $R^{2}$ & 0.002 & 0.028 & 0.002 & 0.028 \\
\hline
\end{tabular}




\section{Table 14 Non-Announcing Connected Firms}

The table reports average estimates of monthly Fama-MacBeth cross-sectional regressions of announcement returns on earnings beta and other control variables for non-announcing connected firms. The dependent variable of model (1) and (2) is announcement return of non-announcing connected firm, defined as cumulative stock return over announcement window $[-1,4]$ of the corresponding announcing firm. The dependent variable of model (3) and (4) is announcement return over announcement window [0,5]. Earnings beta $\left(\beta^{E A}\right)$ is estimated based on daily returns over the 3-year rolling window. Control variables are the same as those in Table $7 . *, * *$, and $* * *$ denote significance at the $10 \%, 5 \%$, and $1 \%$ levels, respectively. The t-statistics of regression estimates are based on Newey-West standard errors with 12 lags.

\begin{tabular}{|c|c|c|c|c|}
\hline \multirow[b]{3}{*}{$\beta^{E A}$} & \multicolumn{2}{|c|}{ Announcement Window $[-1,4]$} & \multicolumn{2}{|c|}{ Announcement Window $[0,5]$} \\
\hline & (1) & (2) & (3) & $(4)$ \\
\hline & $\begin{array}{c}0.039 * * \\
(1.98)\end{array}$ & $\begin{array}{l}0.030 * \\
(1.65)\end{array}$ & $\begin{array}{c}0.049 * * \\
(2.58)\end{array}$ & $\begin{array}{c}0.036^{* *} \\
(1.97)\end{array}$ \\
\hline$\beta^{C A P M}$ & & $\begin{array}{l}-0.012 \\
(-0.14)\end{array}$ & & $\begin{array}{l}-0.017 \\
(-0.19)\end{array}$ \\
\hline LNSIZE & & $\begin{array}{l}-0.030 \\
(-0.71)\end{array}$ & & $\begin{array}{l}-0.017 \\
(-0.43)\end{array}$ \\
\hline LNBM & & $\begin{array}{c}0.125^{* * *} \\
(3.81)\end{array}$ & & $\begin{array}{c}0.100^{* * *} \\
(3.36)\end{array}$ \\
\hline MOM & & $\begin{array}{l}-0.020 \\
(-0.26)\end{array}$ & & $\begin{array}{l}-0.009 \\
(-0.12)\end{array}$ \\
\hline IVOL & & $\begin{array}{l}-0.038 \\
(-0.62)\end{array}$ & & $\begin{array}{l}-0.024 \\
(-0.39)\end{array}$ \\
\hline ILLIQ & & $\begin{array}{l}0.013 \\
(0.77)\end{array}$ & & $\begin{array}{l}0.020 \\
(1.21)\end{array}$ \\
\hline LRET & & $\begin{array}{l}-0.365 \\
(-1.48)\end{array}$ & & $\begin{array}{c}-0.473^{* *} \\
(-2.05)\end{array}$ \\
\hline LEV & & $\begin{array}{c}-0.500 * * * \\
(-4.43)\end{array}$ & & $\begin{array}{c}-0.352 * * * \\
(-2.88)\end{array}$ \\
\hline IO & & $\begin{array}{l}-0.005 \\
(-0.19)\end{array}$ & & $\begin{array}{l}0.008 \\
(0.32)\end{array}$ \\
\hline COV & & $\begin{array}{l}0.031 \\
(1.38)\end{array}$ & & $\begin{array}{l}0.035 \\
(1.61)\end{array}$ \\
\hline LSUE & & $\begin{array}{l}0.084 \\
(1.55)\end{array}$ & & $\begin{array}{l}0.073 \\
(1.46)\end{array}$ \\
\hline $\mathrm{N}$ & 334,622 & 315,518 & 334,622 & 315,518 \\
\hline Adj. $\mathrm{R}^{2}$ & 0.003 & 0.034 & 0.003 & 0.033 \\
\hline
\end{tabular}




\section{Appendix}

To explore the information content of earnings announcement returns, we perform tests similar to Savor and Wilson (2016). We regress future aggregate earnings growth on average earnings announcement returns. Aggregate earnings growth is seasonally adjusted, i.e. $\mathrm{EG}_{\mathrm{t}}=$ $\left(E_{t}-E_{t-4}\right) / P_{t-4}$ where $E_{t}$ is aggregate earnings in quarter $t$ and $P_{t-4}$ is aggregate market capitalization in quarter $t-4$. Average earnings announcement return $\left(\operatorname{CEAR}_{[-1,1]}\right)$ is quarterly announcement return based on cumulative monthly average announcement return at announcement window $[-1,1]$ for all announcing firms. We show that earnings announcement returns predict future aggregate earnings and subsume the predictive power of market returns. The results suggest that aggregate earnings news is concentrated in stock returns during earnings announcement window.

\section{Table A1 Earnings Announcement Returns and Aggregate Cash-flow Information}

The table reports estimates of OLS regression of future quarterly aggregate earnings growth on average earnings announcement returns and other control variables. Earnings growth $\left(E G_{t}\right)$ is seasonally adjusted based on the difference between aggregate earnings in quarter $t$ and aggregate earnings in quarter $t-4$, scaled by total market equity. $\operatorname{CEAR}_{[-1,1]}$ is defined as the average earnings announcement return at announcement window $[-1,1]$ of all announcing firms in each month, compounded over a quarter. Control variables include market excess return (MKTRF), quarterly factor returns of small minus big (SML) portfolio, high minus low (HML) portfolio, robust minus weak (RMD) portfolio, conservative minus aggressive (CMA) portfolio and up minus down (UMD) portfolio. *, **, and *** denote significance at the $10 \%$, 5\%, and $1 \%$ levels, respectively. The t-statistics are reported in parentheses.

\begin{tabular}{|c|c|c|c|c|c|}
\hline & $\begin{array}{c}E G_{t+1} \\
(1)\end{array}$ & $\begin{array}{c}\mathrm{EG}_{\mathrm{t+1}} \\
(2)\end{array}$ & $\begin{array}{c}\mathrm{EG}_{\mathrm{t+1}} \\
\text { (3) }\end{array}$ & $\begin{array}{c}E G_{t+1} \\
(4)\end{array}$ & $\begin{array}{c}\mathrm{EG}_{\mathrm{t}+2} \\
(5)\end{array}$ \\
\hline $\operatorname{CEAR}_{[-1,1]}$ & $\begin{array}{c}0.084 * * * \\
(3.37)\end{array}$ & & $\begin{array}{c}0.082^{* *} \\
(2.15)\end{array}$ & $\begin{array}{c}0.079 * * \\
(2.20)\end{array}$ & $\begin{array}{c}0.104^{* * *} \\
(2.77)\end{array}$ \\
\hline MKTRF & & $\begin{array}{c}0.017 * * \\
(2.54)\end{array}$ & $\begin{array}{l}0.001 \\
(0.06)\end{array}$ & $\begin{array}{l}-0.001 \\
(-0.06)\end{array}$ & $\begin{array}{l}-0.014 \\
(-1.53)\end{array}$ \\
\hline SMB & & & & $\begin{array}{l}-0.010 \\
(-0.86)\end{array}$ & $\begin{array}{l}-0.015 \\
(-1.20)\end{array}$ \\
\hline HML & & & & $\begin{array}{l}-0.017 \\
(-1.48)\end{array}$ & $\begin{array}{c}-0.021^{*} \\
(-1.71)\end{array}$ \\
\hline RMD & & & & $\begin{array}{l}-0.008 \\
(-0.70)\end{array}$ & $\begin{array}{l}-0.010 \\
(-0.87)\end{array}$ \\
\hline CMA & & & & $\begin{array}{c}0.048^{* * *} \\
(2.83)\end{array}$ & $\begin{array}{l}0.023 \\
(1.30)\end{array}$ \\
\hline UMD & & & & $\begin{array}{c}-0.015^{* *} \\
(-2.29)\end{array}$ & $\begin{array}{c}-0.036 * * * \\
(-5.28)\end{array}$ \\
\hline$E G_{t}$ & & & & $\begin{array}{c}0.485^{* * *} \\
(6.50)\end{array}$ & $\begin{array}{c}0.325^{* * * *} \\
(4.17)\end{array}$ \\
\hline $\mathrm{EG}_{\mathrm{t}-1}$ & & & & $\begin{array}{l}0.061 \\
(0.73)\end{array}$ & $\begin{array}{l}0.116 \\
(1.32)\end{array}$ \\
\hline$E G_{t-2}$ & & & & $\begin{array}{l}0.139 * \\
(1.66)\end{array}$ & $\begin{array}{c}-0.262 * * * \\
(-2.98)\end{array}$ \\
\hline$E G_{t-3}$ & & & & $\begin{array}{c}-0.273 * * * \\
(-3.63)\end{array}$ & $\begin{array}{l}0.015 \\
(0.19)\end{array}$ \\
\hline $\mathrm{N}$ & 152 & 152 & 152 & 152 & 152 \\
\hline Adj. $R^{2}$ & 0.064 & 0.035 & 0.058 & 0.424 & 0.368 \\
\hline
\end{tabular}




\section{Table A2 Earnings Beta and Stock Returns: Dimson (1979) Approach}

Panel A reports average estimates of Fama-MacBeth cross-sectional regressions of monthly stock returns on earnings beta interacting with announcement dummy, and other control variables. Panel B reports estimates of panel regressions with time fixed effects. Earnings beta under Dimson (1979) estimation approach $\left(\beta^{C F(D)}\right)$ is estimated based on daily returns over the 3-year rolling window. The announcement dummy is defined as $d^{A N N}=1$ if a firm has earnings announcement in the return month. In model (3) and (4), $d^{A N N}=1$ if a firm has either earnings or M\&A announcement in the return month. $d^{N A N N}$ is the dummy for non-announcing firms, defined as $1-d^{A N N}$. Control variables are the same as those in Table $7 . *$, **, and *** denote significance at the $10 \%, 5 \%$, and $1 \%$ levels, respectively. For Fama-MacBeth regressions, the t-statistics are based on Newey-West standard errors with 12 lags. For panel regressions, the t-statistics are based on standard errors clustered by time.

Panel A: Fama-MacBeth Regressions

\begin{tabular}{|c|c|c|c|c|}
\hline \multirow[b]{3}{*}{$\beta^{E A(D) *} d^{A N N}$} & \multicolumn{2}{|c|}{ Earnings Announcement } & \multicolumn{2}{|c|}{ Earnings or M\&A Announcement } \\
\hline & $(1)$ & $(2)$ & $(3)$ & $(4)$ \\
\hline & $\begin{array}{c}0.079 * * * \\
(3.38)\end{array}$ & $\begin{array}{c}0.065^{* * *} \\
(2.85)\end{array}$ & $\begin{array}{c}0.082^{* * *} \\
(3.80)\end{array}$ & $\begin{array}{c}0.071^{* * *} \\
(3.30)\end{array}$ \\
\hline$\beta^{E A(D) *} d^{N A N N}$ & $\begin{array}{l}0.004 \\
(0.35)\end{array}$ & $\begin{array}{l}0.008 \\
(0.74)\end{array}$ & $\begin{array}{c}0.003 \\
(0.22)\end{array}$ & $\begin{array}{l}0.007 \\
(0.59)\end{array}$ \\
\hline$d^{A N N}$ & $\begin{array}{c}0.347^{* * *} \\
(6.30)\end{array}$ & $\begin{array}{c}0.403^{* * *} \\
(7.30)\end{array}$ & $\begin{array}{c}0.394 * * * \\
(7.03)\end{array}$ & $\begin{array}{c}0.450 * * * \\
(7.97)\end{array}$ \\
\hline$\beta^{C A P M}$ & & $\begin{array}{l}0.020 \\
(0.09)\end{array}$ & & $\begin{array}{l}0.019 \\
(0.08)\end{array}$ \\
\hline LNSIZE & & $\begin{array}{c}-0.206 * * \\
(-2.38)\end{array}$ & & $\begin{array}{c}-0.206 * * \\
(-2.39)\end{array}$ \\
\hline LNBM & & $\begin{array}{c}0.203^{* * *} \\
(4.16)\end{array}$ & & $\begin{array}{c}0.204^{* * *} \\
(4.18)\end{array}$ \\
\hline MOM & & $\begin{array}{l}0.331 \\
(1.60)\end{array}$ & & $\begin{array}{l}0.330 \\
(1.60)\end{array}$ \\
\hline IVOL & & $\begin{array}{c}-0.179 * \\
(-1.87)\end{array}$ & & $\begin{array}{c}-0.177^{*} \\
(-1.85)\end{array}$ \\
\hline ILLIQ & & $\begin{array}{c}0.037 * * * \\
(4.12)\end{array}$ & & $\begin{array}{c}0.036^{* * * *} \\
(4.12)\end{array}$ \\
\hline LRET & & $\begin{array}{c}-4.003 * * * \\
(-9.22)\end{array}$ & & $\begin{array}{c}-4.005 * * * \\
(-9.23)\end{array}$ \\
\hline LEV & & $\begin{array}{c}-0.509 * * \\
(-2.01)\end{array}$ & & $\begin{array}{c}-0.510^{* *} \\
(-2.01)\end{array}$ \\
\hline IO & & $\begin{array}{l}0.062 \\
(1.47)\end{array}$ & & $\begin{array}{l}0.062 \\
(1.48)\end{array}$ \\
\hline $\mathrm{COV}$ & & $\begin{array}{l}0.028 \\
(1.09)\end{array}$ & & $\begin{array}{l}0.029 \\
(1.11)\end{array}$ \\
\hline LSUE & & $\begin{array}{c}0.269 * * * \\
(6.15)\end{array}$ & & $\begin{array}{c}0.269 * * * \\
(6.15)\end{array}$ \\
\hline $\mathrm{N}$ & $1,537,488$ & $1,456,761$ & $1,537,488$ & $1,456,761$ \\
\hline Adj. $R^{2}$ & 0.002 & 0.062 & 0.002 & 0.062 \\
\hline
\end{tabular}


Panel B: Panel Regressions

\begin{tabular}{|c|c|c|c|c|}
\hline \multirow[b]{3}{*}{$\beta^{E A(D) *} d^{A N N}$} & \multicolumn{2}{|c|}{ Earnings Announcement } & \multicolumn{2}{|c|}{ Earnings or M\&A Announcement } \\
\hline & $(1)$ & $(2)$ & (3) & $(4)$ \\
\hline & $\begin{array}{c}0.044^{* *} \\
(2.52)\end{array}$ & $\begin{array}{c}0.044 * * \\
(2.50)\end{array}$ & $\begin{array}{c}0.048^{* * *} \\
(2.71)\end{array}$ & $\begin{array}{c}0.048 * * * \\
(2.74)\end{array}$ \\
\hline$\beta^{E A(D) *} d^{N A N N}$ & $\begin{array}{l}0.011 \\
(0.85)\end{array}$ & $\begin{array}{l}0.010 \\
(0.84)\end{array}$ & $\begin{array}{l}0.009 \\
(0.71)\end{array}$ & $\begin{array}{l}0.008 \\
(0.66)\end{array}$ \\
\hline$d^{A N N}$ & $\begin{array}{c}0.286^{* * *} \\
(3.20)\end{array}$ & $\begin{array}{c}0.258^{* * * *} \\
(3.12)\end{array}$ & $\begin{array}{c}0.326 * * * \\
(3.72)\end{array}$ & $\begin{array}{c}0.301^{* * *} \\
(3.74)\end{array}$ \\
\hline$\beta^{C A P M}$ & & $\begin{array}{l}0.014 \\
(0.05)\end{array}$ & & $\begin{array}{l}0.013 \\
(0.05)\end{array}$ \\
\hline LNSIZE & & $\begin{array}{c}-0.209 * * * \\
(-2.73)\end{array}$ & & $\begin{array}{c}-0.210 * * * \\
(-2.74)\end{array}$ \\
\hline LNBM & & $\begin{array}{c}0.277 * * * \\
(3.95)\end{array}$ & & $\begin{array}{c}0.277 * * * \\
(3.96)\end{array}$ \\
\hline MOM & & $\begin{array}{l}0.250 \\
(1.07)\end{array}$ & & $\begin{array}{l}0.249 \\
(1.06)\end{array}$ \\
\hline IVOL & & $\begin{array}{l}-0.061 \\
(-0.39)\end{array}$ & & $\begin{array}{l}-0.060 \\
(-0.38)\end{array}$ \\
\hline ILLIQ & & $\begin{array}{c}0.010^{* * *} \\
(2.59)\end{array}$ & & $\begin{array}{c}0.010^{* * *} \\
(2.59)\end{array}$ \\
\hline LRET & & $\begin{array}{c}-3.398 * * * \\
(-3.27)\end{array}$ & & $\begin{array}{c}-3.399 * * * \\
(-3.27)\end{array}$ \\
\hline LEV & & $\begin{array}{c}-0.451^{*} \\
(-1.85)\end{array}$ & & $\begin{array}{c}-0.451^{*} \\
(-1.85)\end{array}$ \\
\hline IO & & $\begin{array}{l}0.055 \\
(1.18)\end{array}$ & & $\begin{array}{l}0.055 \\
(1.18)\end{array}$ \\
\hline $\mathrm{COV}$ & & $\begin{array}{c}0.073 * * \\
(2.55)\end{array}$ & & $\begin{array}{c}0.073^{* *} \\
(2.58)\end{array}$ \\
\hline LSUE & & $\begin{array}{c}0.224^{* * * *} \\
(3.63)\end{array}$ & & $\begin{array}{c}0.224^{* * *} \\
(3.63)\end{array}$ \\
\hline $\mathrm{N}$ & $1,537,488$ & $1,456,761$ & $1,537,488$ & $1,456,761$ \\
\hline Adj. $R^{2}$ & 0.113 & 0.120 & 0.113 & 0.120 \\
\hline
\end{tabular}

